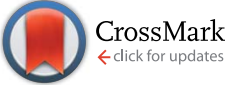

Cite this: RSC Adv., 2017, 7, 5167
Received 7th October 2016 Accepted 17th November 2016

DOI: $10.1039 / \mathrm{c} 6 \mathrm{ra} 24833 \mathrm{k}$

www.rsc.org/advances

\title{
Sesquiterpenoids and monoterpenoid coumarins from Parasenecio rubescens $\dagger$
}

\begin{abstract}
An Jin, ${ }^{\text {ab }}$ Wenming $\mathrm{Wu}^{\mathrm{a}}$ and Hanli Ruan*a
Ten new sesquiterpenoids (1-2, 5-9, 12-14) and four new monoterpenoid coumarins (15-18), along with four known sesquiterpenoids $(3,4,10,11)$ and one known monoterpenoid coumarin (19), were isolated from the whole plant of Parasenecio rubescens. The structures of the isolates were determined through comprehensive spectroscopic analyses and HRESIMS data, with the isolated sesquiterpenoids being classified into oplopane-type (1-4) and bisabolane-type (5-14). The absolute configuration of 1 was established by single-crystal $\mathrm{X}$-ray diffraction analysis with $\mathrm{Cu} \mathrm{K} \alpha$ radiation. The cytotoxic effects against three cancer cell lines (B16 mouse melanoma cells, HepG2 human hepatocellular carcinoma cells, and MCF7 human breast adenocarcinoma cells) of the isolated compounds, as well as their antimicrobial effects against Staphylococcus aureus, Escherichia coli, and Monilia albicans, were evaluated. This study demonstrates that the unusual monoterpenoid coumarins, highly oxygenated oplopane-type and bisabolane-type sesquiterpenoids could have an important chemotaxonomic significance for the genus Parasenecio.
\end{abstract}

\section{Introduction}

Consisting of more than 60 species ( 43 endemic in China), the genus Parasenecio of the family Compositae finds its main distribution in East Asia, the Sino-Himalayan region, and Russia. ${ }^{1}$ More than 20 species of this genus have been used as Chinese folk medicines for the treatment of swelling, inflammation, dysentery, and so on. According to the International Code of Botanical Nomenclature (ICBN), the genus Parasenecio had been misnamed as European herb Cacalia L., the type species of which was first classified as Cacalia alpina L., and then transferred to Adenostyles alpina (L.) Bluff \& Fingerh. The former species of Cacalia are now divided into a few different genera, such as Parasenecio, Arnoglossum, and Adenostyles. ${ }^{2}$ Although the first investigation on Parasenecio was undertaken over decades ago, ${ }^{3}$ plants of the genus haven't received much interest in recent years due to their limited new bioactive secondary metabolites reported. So far, phytochemical studies have been carried out on more than a dozen species of this genus with the described chemical constituents mainly being eremophilanes..$^{4-9}$ Parasenecio rubescens, a perennial herb, is mainly distributed in forest understories and margins, and thickets in valleys of the Anhui, Fujian, Hunan, and Jiangxi

${ }^{a}$ School of Pharmacy, Tongji Medical College, Huazhong University of Science and Technology, Hubei Key Laboratory of Natural Medicinal Chemistry and Resource Evaluation, Wuhan 430030, China. E-mail: ruanhl@mails.tjmu.edu.cn ${ }^{b}$ School of Pharmacy, Hunan University of Medicine, Huaihua 418000, China $\dagger$ Electronic supplementary information (ESI) available. CCDC 1472359. For ESI and crystallographic data in CIF or other electronic format see DOI: 10.1039/c6ra24833k
Provinces of China. This herb has long been employed as a folk medicinal herb for the treatment of tussis, tonsillitis, and tuberculosis. ${ }^{10}$

In our previous research paper on $P$. rubescens, ${ }^{11}$ we described the isolation, structural elucidation and bioactivities of 22 new highly oxygenated bisabolane-type sesquiterpenoids, which was the first isolation of bisabolanes from the genus Parasenecio. Inspired by those works, and also to continue the search for diverse bioactive compounds from Chinese herbs, we have kept studying on the whole plant of $P$. rubescens. As a result, ten new sesquiterpenoids $(\mathbf{1}-\mathbf{2}, \mathbf{5 - 9}, \mathbf{1 2 - 1 4})$ and four new monoterpenoid coumarins (15-18), along with four known sesquiterpenoids $(\mathbf{3}, \mathbf{4}, \mathbf{1 0}, \mathbf{1 1})$ and one known monoterpenoid coumarin (19), were isolated. The isolated sesquiterpenoids were classified into oplopane-type (1-4) and bisabolane-type (5-14). This paper describes the continued work of the identification and characterization of secondary metabolites from $P$. rubescens and the evaluation of their cytotoxic and antimicrobial effects.

\section{Results and discussion}

The air-dried whole plant of $P$. rubescens $(18.4 \mathrm{~kg}$ ) was grounded into powder, and then extracted with $90 \%$ acetone at room temperature. The whole extract was sequentially partitioned with petroleum ether and EtOAc. The EtOAc-soluble fraction was subjected to column chromatography involving MCI gel, silica gel, reversed-phase C18 silica gel, Sephadex LH-20, and then purified by preparative HPLC to yield compounds 1-19 (Fig. 1). 


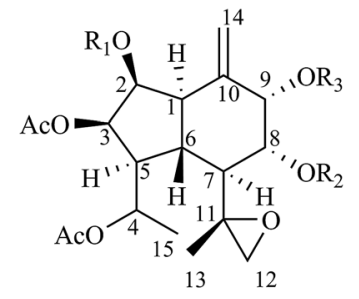

$\begin{array}{lll}\mathrm{R}_{1} & \mathrm{R}_{2} & \mathrm{R}_{3}\end{array}$

1 Mebu Ang MesenOAc

2 Ac Mebu MesenOAc

3 Mebu Mebu Mesen

4 Mebu Mebu MesenOAc

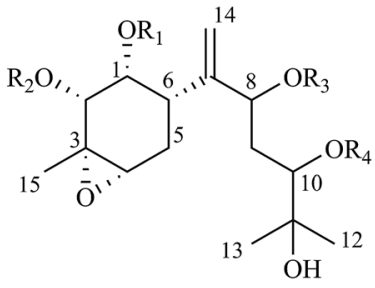

$\begin{array}{llll}R_{1} & R_{2} & R_{3} & R_{4}\end{array}$

7 Ac Mebu Ang $\mathrm{H}$

8 Ac Mesen $\mathrm{H}$ Ang

9 Ac Mesen Ang $\mathrm{H}$

$10 \mathrm{Ac}$ Ang Ang $\mathrm{H}$

11 Ac Ang $\mathrm{H}$ Ang

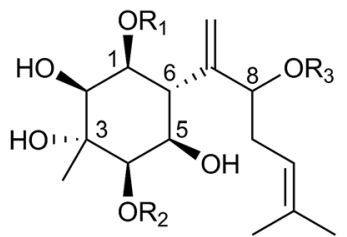

$\begin{array}{lll}R_{1} & R_{2} & R_{3}\end{array}$

5 Ang $\mathrm{H}$ Ang

6 Ac Ang Ang

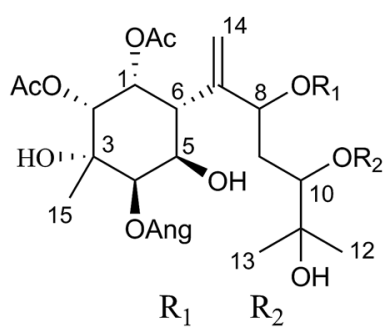

$12 \mathrm{H}$ Ang

13 Ang $\mathrm{H}$<smiles>CC=C(C)C(=O)CC=[15CH]</smiles>

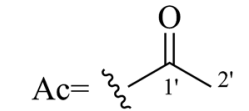<smiles>CCC(=O)C=C(C)CC</smiles><smiles>C=CCC(=O)C(C)CC</smiles><smiles>COC(=O)CCC(=O)C=C(C)C(C)OC(C)=O</smiles><smiles>CC1(CCOc2ccc3ccc(=O)oc3c2)CC1C(=O)C1OC1(C)C</smiles><smiles>COC(C)(C)CC(=O)C1OC1(C)CCOc1ccc2ccc(=O)oc2c1</smiles>

17<smiles>CC(C)=CC(=O)C1OC1(C)CCOc1ccc2ccc(=O)oc2c1</smiles><smiles>CC(C)=CC(=O)C=C(C)CCOc1ccc2ccc(=O)oc2c1</smiles>

Fig. 1 Structures of compounds 1-19.

\section{Oplopane-type sesquiterpenoids}

Pararunine A (1) was isolated as colorless crystals. Its molecular formula was established as $\mathrm{C}_{37} \mathrm{H}_{52} \mathrm{O}_{13}$, with 12 indices of hydrogen deficiency by the HRESIMS and ${ }^{13} \mathrm{C}$ NMR data. The ${ }^{1} \mathrm{H}$ and ${ }^{13} \mathrm{C}$ NMR data (Tables 1 and 2) displayed characteristic signals for one (2-methylbutanoyl)oxy group $\left[\delta_{\mathrm{H}} 2.43(1 \mathrm{H}, \mathrm{m}, \mathrm{H}-\right.$ $\left.2^{\prime}\right), 1.49\left(1 \mathrm{H}, \mathrm{m}, \mathrm{H}-3^{\prime}\right), 1.78\left(1 \mathrm{H}, \mathrm{m}, \mathrm{H}-3^{\prime}\right), 0.98(3 \mathrm{H}, \mathrm{t}, J=7.2, \mathrm{H}-$

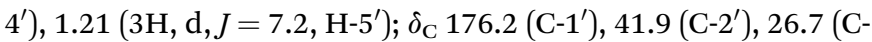
$\left.3^{\prime}\right), 12.1\left(\mathrm{C}-4^{\prime}\right), 17.7\left({\mathrm{C}-5^{\prime \prime}}^{\prime \prime}\right)$, two acetoxy groups $\left[\delta_{\mathrm{H}} 2.04(3 \mathrm{H}, \mathrm{s}, \mathrm{H}-\right.$ $\left.\left.2^{\prime \prime}\right) ; \delta_{\mathrm{C}} 170.0\left(\mathrm{C}-1^{\prime \prime}\right), 21.2\left(\mathrm{C}-2^{\prime \prime}\right)\right],\left[\delta_{\mathrm{H}} 2.09\left(3 \mathrm{H}, \mathrm{s}, \mathrm{H}-2^{\prime \prime \prime}\right) ; \delta_{\mathrm{C}} 170.0\right.$
$\left.\left(\mathrm{C}-1^{\prime \prime \prime}\right), 21.3\left(\mathrm{C}-2^{\prime \prime \prime}\right)\right]$, one angeloyloxy group $\left[\delta_{\mathrm{H}} 6.09(1 \mathrm{H}, \mathrm{qq}, J=\right.$ 7.0, $\left.1.4 \mathrm{~Hz}, \mathrm{H}-3^{\prime \prime \prime \prime}\right), 1.98\left(3 \mathrm{H}, \mathrm{dq}, J=7.0,1.4 \mathrm{~Hz}, \mathrm{H}-4^{\prime \prime \prime \prime}\right), 1.88(3 \mathrm{H}$, $\left.\mathrm{q}, J=1.4 \mathrm{~Hz}, \mathrm{H}-5^{\prime \prime \prime \prime}\right) ; \delta_{\mathrm{C}} 167.2\left(\mathrm{C}-1^{\prime \prime \prime \prime}\right), 127.6\left(\mathrm{C}-2^{\prime \prime \prime \prime}\right), 139.4\left(\mathrm{C}-3^{\prime \prime \prime \prime}\right)$, $\left.15.9\left(\mathrm{C}-4^{\prime \prime \prime \prime}\right), 20.4\left(\mathrm{C}-5^{\prime \prime \prime \prime}\right)\right]$, one (4-acetoxy-4-methylsenecioyl)oxy group $\left[\delta_{\mathrm{H}} 5.81\left(1 \mathrm{H}\right.\right.$, brs, H-2 $\left.{ }^{\prime \prime \prime \prime \prime}\right), 5.23(1 \mathrm{H}, \mathrm{q}, J=6.7 \mathrm{~Hz}, \mathrm{H}-$ $\left.4^{\prime \prime \prime \prime \prime}\right), 1.33\left(3 \mathrm{H}, \mathrm{d}, J=6.7 \mathrm{~Hz}, \mathrm{H}-5^{\prime \prime \prime \prime \prime}\right), 2.08$ (3H, brs, H-6 $\left.6^{\prime \prime \prime \prime \prime}\right), 1.97$

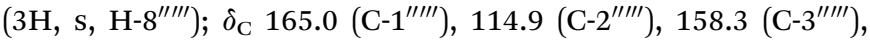
$73.7\left(\mathrm{C}-4^{\prime \prime \prime \prime \prime}\right), 19.3\left(\mathrm{C}-5^{\prime \prime \prime \prime \prime}\right), 15.4\left(\mathrm{C}-6^{\prime \prime \prime \prime \prime}\right), 170.4\left(\mathrm{C}-7^{\prime \prime \prime \prime \prime}\right), 21.2$ (C$\left.\left.8^{\prime \prime \prime \prime \prime}\right)\right]$, one epoxy group $\left[\delta_{\mathrm{H}} 2.74(1 \mathrm{H}, \mathrm{s}, \mathrm{H}-12 \mathrm{a}), 2.83(1 \mathrm{H}, \mathrm{s}, \mathrm{H}-\right.$ $12 \mathrm{~b}) ; \delta_{\mathrm{C}} 55.3(\mathrm{C}-11), 53.2(\mathrm{C}-12)$ ], and a terminal double bond 
Table $1{ }^{13} \mathrm{C}$ NMR data for compounds $1,2,5-9,12-18(100 \mathrm{MHz})$

\begin{tabular}{|c|c|c|c|c|c|c|c|c|c|c|c|c|c|c|c|c|}
\hline No. & $\mathbf{1}^{a}$ & $2^{a}$ & No. & $5^{a}$ & $6^{a}$ & $7^{b}$ & $\mathbf{8}^{b}$ & $\mathbf{9}^{b}$ & $12^{b}$ & $13^{b}$ & $14^{b}$ & No. & $15^{a}$ & $16^{a}$ & $17^{a}$ & $18^{a}$ \\
\hline 1 & 44.9 & 44.5 & 1 & 71.9 & 72.5 & 70.3 & 71.5 & 70.5 & 72.9 & 71.5 & 75.2 & 2 & 161.2 & 161.2 & 161.3 & 161.1 \\
\hline 2 & 71.2 & 71.7 & 2 & 75.2 & 75.0 & 73.5 & 72.8 & 72.8 & 73.8 & 73.7 & 78.6 & 3 & 113.6 & 113.6 & 113.5 & 113.2 \\
\hline 3 & 72.3 & 72.6 & 3 & 71.9 & 72.5 & 58.2 & 58.3 & 58.3 & 74.5 & 74.3 & 75.7 & 4 & 143.4 & 143.4 & 143.5 & 143.4 \\
\hline 4 & 69.9 & 69.9 & 4 & 77.4 & 75.7 & 61.4 & 61.6 & 61.3 & 78.6 & 78.3 & 75.2 & 5 & 129.0 & 129.0 & 129.0 & 128.9 \\
\hline 5 & 45.0 & 44.9 & 5 & 68.5 & 72.6 & 27.0 & 27.2 & 27.0 & 66.2 & 66.4 & 35.8 & 6 & 112.8 & 112.9 & 112.8 & 112.7 \\
\hline 6 & 43.8 & 43.8 & 6 & 44.5 & 41.9 & 38.7 & 36.7 & 38.8 & 41.0 & 42.0 & 43.5 & 7 & 161.8 & 161.8 & 161.8 & 161.8 \\
\hline 7 & 49.4 & 49.2 & 7 & 144.5 & 146.9 & 149.0 & 150.3 & 149.3 & 146.4 & 144.1 & 151.3 & 8 & 101.8 & 101.7 & 101.8 & 101.5 \\
\hline 8 & 72.2 & 72.5 & 8 & 74.3 & 78.8 & 75.9 & 74.7 & 75.7 & 75.8 & 77.8 & 74.3 & 9 & 156.0 & 156.1 & 156.1 & 155.8 \\
\hline 9 & 73.6 & 73.4 & 9 & 34.0 & 31.6 & 37.3 & 36.5 & 37.3 & 35.2 & 37.0 & 37.8 & 10 & 113.0 & 113.1 & 112.9 & 112.7 \\
\hline 10 & 137.9 & 137.9 & 10 & 119.5 & 119.8 & 75.5 & 77.8 & 75.5 & 77.8 & 75.7 & 75.7 & $1^{\prime}$ & 65.3 & 65.1 & 65.4 & 65.0 \\
\hline 11 & 55.3 & 55.3 & 11 & 134.6 & 134.4 & 73.5 & 72.6 & 73.5 & 72.8 & 73.5 & 73.5 & $2^{\prime}$ & 31.5 & 31.4 & 31.3 & 31.8 \\
\hline 12 & 53.2 & 53.2 & 12 & 25.9 & 25.9 & 25.0 & 26.8 & 25.0 & 25.4 & 25.5 & 25.2 & $3^{\prime}$ & 62.2 & 63.1 & 62.5 & 61.9 \\
\hline 13 & 16.7 & 16.5 & 13 & 25.2 & 18.1 & 25.7 & 26.8 & 25.7 & 26.8 & 25.0 & 25.2 & $4^{\prime}$ & 65.5 & 63.8 & 66.5 & 66.1 \\
\hline 14 & 115.5 & 115.3 & 14 & 118.1 & 110.3 & 114.8 & 114.9 & 114.6 & 116.7 & 117.8 & 109.8 & $5^{\prime}$ & 205.7 & 201.8 & 204.7 & 194.7 \\
\hline 15 & 16.4 & 16.3 & 15 & 18.1 & 24.4 & 19.8 & 19.8 & 19.8 & 23.8 & 23.7 & 23.7 & $6^{\prime}$ & 50.4 & 65.1 & 52.5 & 121.2 \\
\hline $1^{\prime}$ & 176.2 & 169.9 & $1^{\prime}$ & 167.2 & 170.5 & 172.2 & 172.6 & 172.3 & 168.2 & 168.0 & 168.7 & $7^{\prime}$ & 24.6 & 62.1 & 75.1 & 159.3 \\
\hline $2^{\prime}$ & 41.9 & 21.4 & $2^{\prime}$ & 127.8 & 21.1 & 20.9 & 20.9 & 20.8 & 128.9 & 128.9 & 128.9 & $8^{\prime}$ & 22.8 & 19.0 & 24.8 & 21.4 \\
\hline $3^{\prime}$ & 26.7 & & $3^{\prime}$ & 139.0 & & & & & 140.2 & 140.2 & 137.4 & $9^{\prime}$ & 22.8 & 25.1 & 25.2 & 28.1 \\
\hline $4^{\prime}$ & 12.1 & & $4^{\prime}$ & 16.0 & & & & & 16.3 & 16.3 & 16.0 & $10^{\prime}$ & 22.7 & 22.5 & 22.8 & 22.7 \\
\hline $5^{\prime}$ & 17.7 & & $5^{\prime}$ & 20.6 & & & & & 20.7 & 21.1 & 20.8 & $\mathrm{OCH}_{3}$ & & & 49.6 & \\
\hline $1^{\prime \prime}$ & 170.0 & 169.8 & $1^{\prime \prime}$ & 168.6 & 166.4 & 177.0 & 167.2 & 167.1 & 172.0 & 171.8 & 168.1 & & & & & \\
\hline $2^{\prime \prime}$ & 21.2 & 21.2 & $2^{\prime \prime}$ & 127.8 & 127.1 & 42.5 & 114.6 & 114.6 & 21.1 & 20.6 & 128.3 & & & & & \\
\hline $1^{\prime \prime \prime}$ & 170.0 & 170.2 & $3^{\prime \prime}$ & 139.7 & 140.0 & 27.5 & 164.6 & 164.6 & & & 138.7 & & & & & \\
\hline $2^{\prime \prime \prime}$ & 21.3 & 21.1 & $4^{\prime \prime}$ & 16.0 & 16.1 & 12.0 & 34.7 & 34.7 & & & 16.0 & & & & & \\
\hline $1^{\prime \prime \prime \prime}$ & 167.2 & 176.3 & $5^{\prime \prime}$ & 20.6 & 20.9 & 17.2 & 12.4 & 12.3 & & & 20.8 & & & & & \\
\hline $2^{\prime \prime \prime \prime}$ & 127.6 & 41.3 & $6^{\prime \prime}$ & & & & 19.1 & 19.1 & & & & & & & & \\
\hline $3^{\prime \prime \prime \prime}$ & 139.4 & 26.4 & $1^{\prime \prime \prime}$ & & 168.5 & 168.5 & 169.0 & 168.6 & 172.9 & 172.2 & & & & & & \\
\hline $4^{\prime \prime \prime \prime}$ & 15.9 & 11.7 & $2^{\prime \prime \prime}$ & & 127.5 & 129.1 & 129.4 & 129.1 & 21.1 & 20.9 & & & & & & \\
\hline $5^{\prime \prime \prime \prime \prime}$ & 20.4 & 16.4 & $3^{\prime \prime \prime}$ & & 140.3 & 139.5 & 138.9 & 139.5 & & & & & & & & \\
\hline $1^{\prime \prime \prime \prime \prime \prime}$ & 165.0 & 165.0 & $4^{\prime \prime \prime}$ & & 16.0 & 16.2 & 16.0 & 16.2 & & & & & & & & \\
\hline $2^{\prime \prime \prime \prime \prime \prime}$ & 114.9 & 115.0 & $5^{\prime \prime \prime}$ & & 20.6 & 20.9 & 20.8 & 20.9 & & & & & & & & \\
\hline $3^{\prime \prime \prime \prime \prime \prime}$ & 158.3 & 158.3 & $1^{\prime \prime \prime \prime}$ & & & & & & 169.3 & 168.5 & & & & & & \\
\hline $4^{\prime \prime \prime \prime \prime \prime}$ & 73.7 & 73.7 & $2^{\prime \prime \prime \prime}$ & & & & & & 129.4 & 128.9 & & & & & & \\
\hline $5^{\prime \prime \prime \prime \prime \prime}$ & 19.3 & 19.3 & $3^{\prime \prime \prime \prime}$ & & & & & & 138.8 & 140.1 & & & & & & \\
\hline $6^{\prime \prime \prime \prime \prime \prime}$ & 15.4 & 15.4 & $4^{\prime \prime \prime \prime}$ & & & & & & 16.0 & 16.3 & & & & & & \\
\hline $7^{\prime \prime \prime \prime \prime \prime}$ & 170.4 & 170.4 & $5^{\prime \prime \prime \prime}$ & & & & & & 20.9 & 20.9 & & & & & & \\
\hline $8^{\prime \prime \prime \prime \prime \prime}$ & 21.2 & 21.1 & & & & & & & & & & & & & & \\
\hline
\end{tabular}

[ $\delta_{\mathrm{H}} 4.87(1 \mathrm{H}, \mathrm{s}, \mathrm{H}-14 \mathrm{a}), 5.27(1 \mathrm{H}, \mathrm{s}, \mathrm{H}-14 \mathrm{~b}) ; \delta_{\mathrm{C}} 137.9$ (C-10), 115.5 (C-14)], which accounted for 10 of 12 indices of hydrogen deficiency, as a result, compound $\mathbf{1}$ was proposed as having a dualring structure.

The ${ }^{1} \mathrm{H}-{ }^{1} \mathrm{H}$ COSY experiment of $\mathbf{1}$ showed clear signals for two main structural sequences, $-\mathrm{CH}(\mathrm{H}-1)-\mathrm{CH}(\mathrm{H}-2)-\mathrm{CH}(\mathrm{H}-3)-$ $\mathrm{CH}(\mathrm{H}-4)-\mathrm{CH}(\mathrm{H}-5)-\mathrm{CH}(\mathrm{H}-6)-\mathrm{CH}_{3}(\mathrm{H}-15)-$ and $-\mathrm{CH}(\mathrm{H}-7)-\mathrm{CH}(\mathrm{H}-$ 8)- $\mathrm{CH}(\mathrm{H}-9)-($ Fig. 2), which were further extended by the following HMBC correlations (Fig. 2): H-1, H-9/C-14 and H-13/C11. The above evidences suggested that 1 was an oplopane-type sesquiterpenoid. ${ }^{12}$ The attachment of one (2-methylbutanoyl) oxy, two acetoxy, one angeloyloxy, and one (4-acetoxy-4methylsenecioyl)oxy groups could also be determined by the HMBC correlations of $\mathrm{H}-2 / \mathrm{C}-1^{\prime}, \mathrm{H}-3 / \mathrm{C}-1^{\prime \prime}, \mathrm{H}-4 / \mathrm{C}-1^{\prime \prime \prime}, \mathrm{H}-8 / \mathrm{C}-\mathbf{1}^{\prime \prime \prime \prime}$, and $\mathrm{H}-9 / \mathrm{C}-\mathrm{1}^{\prime \prime \prime \prime \prime \prime}$, respectively.

The relative configuration of the dual-ring moiety of $\mathbf{1}$ was established by the NOESY correlations (Fig. 2) and ${ }^{1} \mathrm{H}$ NMR coupling constants. When $\mathrm{H}-1$ is assumed to be $\alpha$-oriented, obvious NOESY correlations of $\mathrm{H}-3 / \mathrm{H}-1, \mathrm{H}-1 / \mathrm{H}-7$, and $\mathrm{H}-7 / \mathrm{H}-5$ indicated that $\mathrm{H}-1, \mathrm{H}-3, \mathrm{H}-5$, and $\mathrm{H}-7$ were all oriented on the same side of the molecule and were assigned to be $\alpha$-oriented. $\mathrm{H}-2$ should be $\alpha$-equatorial, based on the small coupling constant of $\mathrm{H}-1 / \mathrm{H}-2\left(J_{1,2}=3.2 \mathrm{~Hz}\right)$, while $\mathrm{H}-6$ should be $\beta$ axial, since the large coupling constant of $\mathrm{H}-1 / \mathrm{H}-6\left(J_{1,6}=11.5\right.$ $\mathrm{Hz}$ ) was observed. For another, NOESY correlations of $\mathrm{H}-6 / \mathrm{H}-8$ revealed that $\mathrm{H}-8$ was $\beta$-oriented, and $\mathrm{H}-9$ must be $\beta$-equatorial due to the small coupling constant $\left(J_{8,9}=3.2 \mathrm{~Hz}\right)$ observed. The absolute configuration of 1 was established as $1 R, 2 S, 3 R, 4 R, 5 S, 6 R, 7 S, 8 R, 9 S, 11 S, 2^{\prime} S, 2^{\prime \prime \prime \prime} Z, 2^{\prime \prime \prime \prime \prime} E, 4^{\prime \prime \prime \prime \prime \prime} S$ by singlecrystal X-ray diffraction using $\mathrm{Cu} \mathrm{K} \alpha$ radiation (Fig. 3). Thus, the chemical structure of $\mathbf{1}$ was established as shown and given the name pararunine $\mathrm{A}$.

Pararunine B (2), a yellow oil, showed a molecular formula of $\mathrm{C}_{34} \mathrm{H}_{48} \mathrm{O}_{13}$ based on its HRESIMS and ${ }^{13} \mathrm{C}$ NMR data. Its ${ }^{1} \mathrm{H}$ and ${ }^{13} \mathrm{C}$ NMR data (Tables 1 and 2) resembled those of compound 1 , which implied that 2 was also an oplopane-type 
Table $2{ }^{1} \mathrm{H}$ NMR data for compounds 1,2 and 5-9 (400 MHz, J in Hz)

\begin{tabular}{|c|c|c|c|c|c|c|c|c|}
\hline No. & $\mathbf{1}^{a}$ & $2^{a}$ & No. & $5^{a}$ & $6^{a}$ & $7^{b}$ & $8^{b}$ & $\mathbf{9}^{b}$ \\
\hline 1 & 2.52 dd $(11.5,3.2)$ & $2.50 \mathrm{dd}(11.9,2.9)$ & 1 & $5.25 \mathrm{dd}(11.7,2.7)$ & 5.48 dd $(11.3,3.2)$ & $5.25 \mathrm{dd}(4.5,1.5)$ & $5.35 \mathrm{dd}(4.4,1.2)$ & 5.26 dd $(4.5,1.4)$ \\
\hline 2 & $5.69 \mathrm{dd}(4.4,3.2)$ & $5.62 \mathrm{dd}(4.2,2.9)$ & 2 & $3.86 \mathrm{~d}(2.7)$ & $3.79 \mathrm{~d}(3.2)$ & $5.35 \mathrm{~d}(4.5)$ & $5.36 \mathrm{~d}(4.4)$ & $5.35 \mathrm{~d}(4.5)$ \\
\hline 4 & $5.23 \mathrm{~m}$ & $5.18 \mathrm{~m}$ & 5 & $4.40 \mathrm{dd}(11.7,2.8)$ & $4.17 \mathrm{dd}(11.3,3.2)$ & $2.12 \mathrm{~m}$ & 2.09 , overlap & 2.12 overlap \\
\hline 5 & 2.76 overlap & 2.74 overlap & 6 & $3.06 \mathrm{t}(11.7)$ & $2.71 \mathrm{t}(11.3)$ & 2.65 dd $(10.9,7.1)$ & $2.61 \mathrm{dd}(11.5,6.5)$ & $2.65 \mathrm{dd}(11.3,7.0)$ \\
\hline 6 & 2.01 overlap & 2.00 overlap & 8 & 5.14 overlap & $4.83 \mathrm{~m}$ & $5.48 \mathrm{dd}(11.0,2.3)$ & $4.07 \mathrm{dd}(8.5,5.0)$ & $5.47 \mathrm{dd}(10.7,2.0)$ \\
\hline 9 & 5.71 brd (3.2) & 5.68 brd (3.1) & 12 & $1.66 \mathrm{~s}$ & $1.69 \mathrm{~s}$ & $1.15 \mathrm{~s}$ & $1.17 \mathrm{~s}$ & $1.15 \mathrm{~s}$ \\
\hline 12 & $\begin{array}{l}2.74 \mathrm{~d}(4.0) \\
2.83 \mathrm{~d}(4.0)\end{array}$ & $\begin{array}{l}2.75 \mathrm{~d}(3.7) \\
2.83 \mathrm{~d}(3.7)\end{array}$ & 13 & $1.59 \mathrm{~s}$ & $1.64 \mathrm{~s}$ & $1.17 \mathrm{~s}$ & $1.19 \mathrm{~s}$ & $1.17 \mathrm{~s}$ \\
\hline 13 & $1.25 \mathrm{~s}$ & $1.21 \mathrm{~s}$ & 14 & $5.26 \mathrm{~s}, 5.33 \mathrm{~s}$ & $5.15 \mathrm{~s}, 5.19 \mathrm{~s}$ & $5.21 \mathrm{~s}, 5.01 \mathrm{~s}$ & $4.99 \mathrm{~s}, 5.06 \mathrm{~s}$ & $5.02 \mathrm{~s}, 5.21 \mathrm{~s}$ \\
\hline 14 & $4.87 \mathrm{~s}, 5.27 \mathrm{~s}$ & $4.87 \mathrm{~s}, 5.26 \mathrm{~s}$ & 15 & $1.60 \mathrm{~s}$ & $1.43 \mathrm{~s}$ & $1.28 \mathrm{~s}$ & $1.28 \mathrm{~s}$ & $1.28 \mathrm{~s}$ \\
\hline 15 & $1.46 \mathrm{~d}(6.7)$ & $1.44 \mathrm{~d}(6.8)$ & $2^{\prime}$ & & $2.03 \mathrm{~s}$ & $2.01 \mathrm{~s}$ & $2.02 \mathrm{~s}$ & $2.00 \mathrm{~s}$ \\
\hline $2^{\prime \prime}$ & $2.04 \mathrm{~s}$ & $2.08 \mathrm{~s}$ & $3^{\prime \prime}$ & $6.13 \mathrm{qq}(7.3,1.2)$ & $6.14 \mathrm{qq}(7.2,1.4)$ & $1.46 \mathrm{~m}, 1.69 \mathrm{~m}$ & & \\
\hline $2^{\prime \prime \prime}$ & $2.09 \mathrm{~s}$ & $2.16 \mathrm{~s}$ & $4^{\prime \prime}$ & $1.98 \mathrm{dq}(7.3,1.2)$ & $2.05 \mathrm{dq}(7.2,1.4)$ & $0.91 \mathrm{t}(7.5)$ & $2.20 \mathrm{q}(7.4)$ & $2.21 \mathrm{q}(7.4)$ \\
\hline $2^{\prime \prime \prime \prime}$ & & $2.39 \mathrm{~m}$ & $5^{\prime \prime}$ & $1.89 \mathrm{q}(1.2)$ & $1.95 \mathrm{q}(1.4)$ & $1.14 \mathrm{~d}(7.0)$ & $1.09 \mathrm{t}(7.4)$ & $1.08 \mathrm{t}(7.4)$ \\
\hline $3^{\prime \prime \prime \prime}$ & $6.09 \mathrm{qq}(7.0,1.4)$ & $1.46 \mathrm{~m}, 1.76 \mathrm{~m}$ & $6^{\prime \prime}$ & & & & $2.16 \mathrm{~s}$ & $2.16 \mathrm{~s}$ \\
\hline $4^{\prime \prime \prime \prime}$ & $1.98 \mathrm{dq}(7.0,1.4)$ & $0.89 \mathrm{t}(7.4)$ & $3^{\prime \prime \prime}$ & & $6.14 \mathrm{qq}(7.2,1.4)$ & $6.13 \mathrm{qq}(7.3,1.5)$ & $6.12 \mathrm{qq}(7.3,1.4)$ & $6.13 \mathrm{qq}(7.3,1.5)$ \\
\hline $5^{\prime \prime \prime \prime}$ & $1.88 \mathrm{q} \mathrm{(1.4)}$ & $1.15 \mathrm{~d}(7.0)$ & $4^{\prime \prime \prime}$ & & $1.97 \mathrm{dq}(7.2,1.4)$ & $1.98 \mathrm{dq}(7.3,1.5)$ & $1.98 \mathrm{dq}(7.3,1.4)$ & $1.98 \mathrm{dq}(7.3,1.5)$ \\
\hline $2^{\prime \prime \prime \prime \prime}$ & $5.81 \mathrm{brs}$ & 5.82 brs & $5^{\prime \prime \prime}$ & & $1.88 \mathrm{q}(1.4)$ & $1.91 \mathrm{q}(1.5)$ & $1.91 \mathrm{q}(1.4)$ & $1.91 \mathrm{q}(1.5)$ \\
\hline $4^{\prime \prime \prime \prime \prime}$ & $5.23 \mathrm{q}(6.7)$ & 5.24 overlap & & & & & & \\
\hline $5^{\prime \prime \prime \prime \prime}$ & $1.33 \mathrm{~d}(6.7)$ & $1.34 \mathrm{~d}(6.8)$ & & & & & & \\
\hline $6^{\prime \prime \prime \prime \prime}$ & $2.08 \mathrm{brs}$ & $2.09 \mathrm{brs}$ & & & & & & \\
\hline $8^{\prime \prime \prime \prime \prime}$ & $1.97 \mathrm{~s}$ & $1.98 \mathrm{~s}$ & & & & & & \\
\hline
\end{tabular}
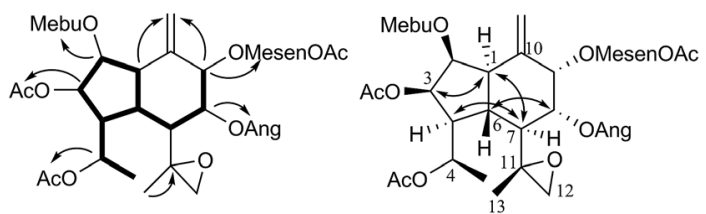

Fig. 2 Key $\mathrm{HMBC}(\rightarrow),{ }^{1} \mathrm{H}-{ }^{1} \mathrm{H}$ COSY (thick lines) and NOESY $(\leftrightarrow)$ correlations of compound 1 .

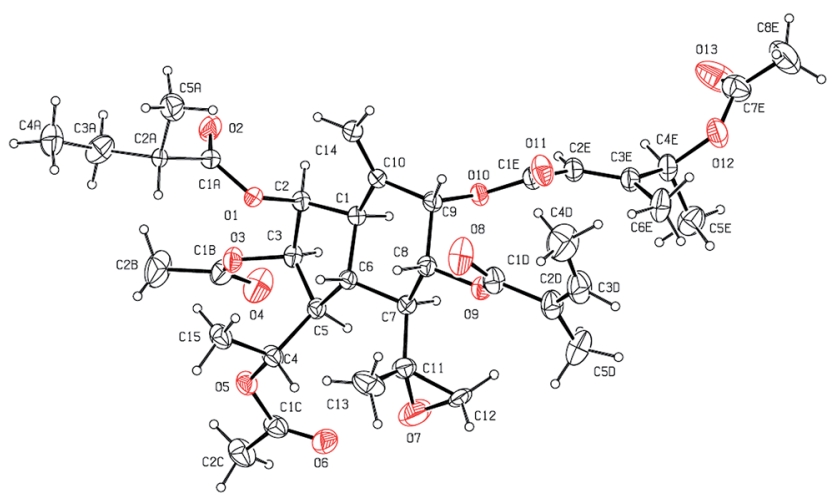

Fig. 3 ORTEP drawing of compound 1. sesquiterpenoid, with the differences being the types and positions of some substituent groups. The three acetoxy, one (2methylbutanoyl)oxy, and one (4-acetoxy-4-methylsenecioyl)oxy groups of 2 were located at C-2, C-3, C-4, C-8, and C-9 via the HMBC correlations of $\mathrm{H}-2 / \mathrm{C}-1^{\prime}, \mathrm{H}-3 / \mathrm{C}-1^{\prime \prime}, \mathrm{H}-4 / \mathrm{C}-1^{\prime \prime \prime}, \mathrm{H}-8 / \mathrm{C}-1^{\prime \prime \prime \prime}$, and $\mathrm{H}-9 / \mathrm{C}-1^{\prime \prime \prime \prime \prime}$, respectively.

The relative configuration of the dual-ring moiety of 2 was deduced using the same methods as those applied for $\mathbf{1}$. Thus, the structure of $\mathbf{2}$ was defined as shown, named pararunine B.

Compounds 3 and 4 were respectively confirmed as $2 \beta, 8 \alpha$ dimethylbutyryloxy-3 $\beta, 4$-diacetoxy- $9 \alpha-\left[\left(4^{\prime \prime \prime \prime \prime \prime}-\right.\right.$ methylsenecioyl $)$ oxy]-11,12-epoxyoplop-10(14)-en, ${ }^{13}$ and $2 \beta, 8 \alpha$-dimethylbutyryl-

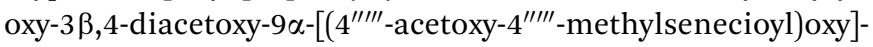
11,12-epoxyoplop-10(14)-en, ${ }^{14}$ by comparing their spectroscopic data with published literature data.

\section{Bisabolane-type sesquiterpenoids}

Pararunine C (5) was obtained as a yellow oil. The molecular formula $\mathrm{C}_{25} \mathrm{H}_{38} \mathrm{O}_{8}$ (7 degrees of unsaturation) was established by HRESIMS analysis and NMR spectroscopic data (Tables 1 and 2). Two angeloyloxy groups were present in $\mathbf{5}$, as supported by the observed ${ }^{1} \mathrm{H}$ and ${ }^{13} \mathrm{C}$ NMR data: $\left[\delta_{\mathrm{H}} 6.07(1 \mathrm{H}, \mathrm{qq}, J=7.3\right.$, $\left.1.2 \mathrm{~Hz}, \mathrm{H}-3^{\prime}\right), 1.98\left(3 \mathrm{H}, \mathrm{dq}, J=7.3,1.2 \mathrm{~Hz}, \mathrm{H}-4^{\prime}\right), 1.87$ (3H, q, $J=$ $\left.1.2 \mathrm{~Hz}, \mathrm{H}-5^{\prime}\right) ; \delta_{\mathrm{C}} 167.2\left(\mathrm{C}-1^{\prime}\right), 127.8\left(\mathrm{C}-2^{\prime}\right), 139.0\left(\mathrm{C}-3^{\prime}\right), 16.0\left(\mathrm{C}-4^{\prime}\right)$, 
$\left.20.6\left(\mathrm{C}-5^{\prime}\right)\right]$, and $\left[\delta_{\mathrm{H}} 6.13\left(1 \mathrm{H}, \mathrm{qq}, J=7.3,1.2 \mathrm{~Hz}, \mathrm{H}-3^{\prime \prime}\right), 1.98(3 \mathrm{H}\right.$, $\left.\mathrm{dq}, J=7.3,1.2 \mathrm{~Hz}, \mathrm{H}-4^{\prime \prime}\right), 1.89\left(3 \mathrm{H}, \mathrm{q}, J=1.2 \mathrm{~Hz}, \mathrm{H}-5^{\prime \prime}\right) ; \delta_{\mathrm{C}} 168.6$ $\left.\left(\mathrm{C}-1^{\prime \prime}\right), 127.8\left(\mathrm{C}-2^{\prime \prime}\right), 139.7\left(\mathrm{C}-3^{\prime \prime}\right), 16.0\left(\mathrm{C}-4^{\prime \prime}\right), 20.6\left(\mathrm{C}-5^{\prime \prime}\right)\right]$. Apart from the two angeloyloxy groups, the ${ }^{13} \mathrm{C}$ NMR and DEPT spectra of 5 showed fifteen more carbon signals, consisting of two double bonds, one quaternary carbon, three methyl groups, one methylene group, and six methine groups including five oxygenated ones. The aforementioned data were similar to those acquired for the known compound pararubin A, which was previously isolated from the same plant. The ${ }^{1} \mathrm{H}-{ }^{1} \mathrm{H}$ COSY correlations (Fig. 4) of $\mathbf{5}$ exhibited two main structural sequences, - $\mathrm{CH}(\mathrm{H}-2)-\mathrm{CH}(\mathrm{H}-1)-\mathrm{CH}(\mathrm{H}-6)-\mathrm{CH}(\mathrm{H}-5)-\mathrm{CH}(\mathrm{H}-4)-$ and $-\mathrm{CH}(\mathrm{H}-8)-\mathrm{CH}_{2}(\mathrm{H}-9)-\mathrm{CH}(\mathrm{H}-10)-$, which were connected to disclose the presence of a bisabolane sesquiterpenoid skeleton by the following HMBC correlations (Fig. 4): H-1, H-5/C-7; $\mathrm{H}-2$, H-4/C-15; H-6, H-8/C-14; H-10/C-12; and $\mathrm{H}-12 / \mathrm{C}-13$. Furthermore, according to the HMBC correlations of $\mathrm{H}-1 / \mathrm{C}-1^{\prime}$ and $\mathrm{H}-8 / \mathrm{C}-\mathrm{I}^{\prime \prime}$, the positions of the two angeloyloxy groups were attached to $\mathrm{C}-1$ and $\mathrm{C}-8$, respectively.

5 shared the same relative configuration of the cyclohexane ring with pararubin $\mathrm{A},{ }^{\mathbf{1 1}}$ which was established by the ${ }^{1} \mathrm{H}$ NMR coupling constants: when $\mathrm{H}-6$ is assumed to be $\beta$-oriented, $\mathrm{H}-1$ and $\mathrm{H}-5$ should be $\alpha$-axial, based on the large coupling constants of $\mathrm{H}-1 / \mathrm{H}-6\left(J_{1,6}=11.7 \mathrm{~Hz}\right)$ and $\mathrm{H}-5 / \mathrm{H}-6\left(J_{5,6}=11.7\right.$ $\mathrm{Hz}$ ). $\mathrm{H}-2$ and $\mathrm{H}-4$ must be $\alpha$-equatorial due to the small coupling constants $\left(J_{1,2}, J_{4,5}=2.7 \mathrm{~Hz}\right)$. Thus, the structure of 5 was established as shown and given the name pararunine $\mathrm{C}$.

Pararunine D (6), a yellow oil, possessed a molecular formula of $\mathrm{C}_{27} \mathrm{H}_{40} \mathrm{O}_{9}$ according to the ${ }^{13} \mathrm{C}$ NMR and HRESIMS data. The ${ }^{1} \mathrm{H}$ and ${ }^{13} \mathrm{C}$ NMR data (Tables 1 and 2 ) were similar to those of 5 . However, one more acetoxy group was observed, indicating that 6 was a bisabolane-type sesquiterpenoid with an acetoxy and two angeloyloxy groups, the positions of which were determined by the HMBC correlations of $\mathrm{H}-1 / \mathrm{C}-1^{\prime}, \mathrm{H}-4 / \mathrm{C}-1^{\prime \prime}$, and $\mathrm{H}-8 / \mathrm{C}-\mathbf{1}^{\prime \prime \prime}$, respectively. Using the same method applied in compound $\mathbf{5}$ permitted the assignment of the relative configuration of 6 . The structure of $\mathbf{6}$ was therefore elucidated, and named pararunine D.

Pararunine E (7), a yellow oil, possessed a molecular formula of $\mathrm{C}_{27} \mathrm{H}_{42} \mathrm{O}_{9}$ based on its ${ }^{13} \mathrm{C}$ NMR and HRESIMS data. The ${ }^{1} \mathrm{H}$ and ${ }^{13} \mathrm{C}$ NMR data (Tables 1 and 2) of 7 showed the presence of one acetoxy group $\left[\delta_{\mathrm{H}} 2.01\left(3 \mathrm{H}, \mathrm{s}, \mathrm{H}-2^{\prime}\right) ; \delta_{\mathrm{C}} 172.2\left(\mathrm{C}-1^{\prime}\right), 20.9(\mathrm{C}-\right.$ $\left.2^{\prime}\right)$, one (2-methylbutanoyl)oxy group $\left[\delta_{\mathrm{H}} 2.36\left(1 \mathrm{H}, \mathrm{m}, \mathrm{H}-2^{\prime \prime}\right)\right.$, $1.46\left(1 \mathrm{H}, \mathrm{m}, \mathrm{H}-3^{\prime \prime}\right), 1.69\left(1 \mathrm{H}, \mathrm{m}, \mathrm{H}-3^{\prime \prime}\right), 0.91(3 \mathrm{H}, \mathrm{t}, J=7.5 \mathrm{~Hz}, \mathrm{H}-$ $\left.4^{\prime \prime}\right), 1.14\left(3 \mathrm{H}, \mathrm{d}, J=7.0 \mathrm{~Hz}, \mathrm{H}-5^{\prime \prime}\right) ; \delta_{\mathrm{C}} 177.0\left(\mathrm{C}-1^{\prime \prime}\right), 42.5\left(\mathrm{C}-2^{\prime \prime}\right)$, $\left.27.5\left(\mathrm{C}-3^{\prime \prime}\right), 12.0\left(\mathrm{C}-4^{\prime \prime}\right), 17.2\left(\mathrm{C}-5^{\prime \prime}\right)\right]$, one angeloyloxy group $\left[\delta_{\mathrm{H}}\right.$ $6.13\left(1 \mathrm{H}, \mathrm{qq}, J=7.3,1.5 \mathrm{~Hz}, \mathrm{H}-3^{\prime \prime \prime}\right), 1.98(3 \mathrm{H}, \mathrm{dq}, J=7.3,1.5 \mathrm{~Hz}$, $\left.\mathrm{H}-4^{\prime \prime \prime}\right), 1.91\left(3 \mathrm{H}, \mathrm{m}, \mathrm{H}-5^{\prime \prime \prime}\right) ; \delta_{\mathrm{C}} 168.5\left(\mathrm{C}-1^{\prime \prime \prime}\right), 129.1\left(\mathrm{C}-2^{\prime \prime \prime}\right), 139.5$
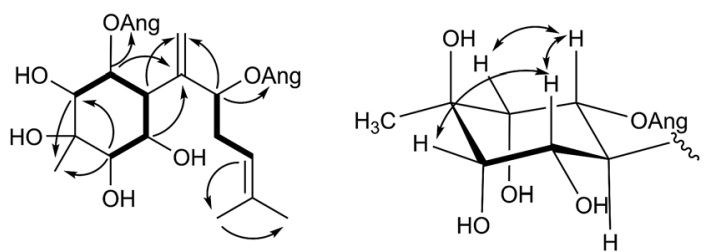

Fig. 4 Key $\operatorname{HMBC}(\rightarrow),{ }^{1} \mathrm{H}-{ }^{1} \mathrm{H}$ COSY (thick lines) and $\operatorname{NOESY}(\leftrightarrow)$ correlations of compound 5 .
$\left.\left(\mathrm{C}-3^{\prime \prime \prime}\right), 16.2\left(\mathrm{C}-4^{\prime \prime \prime}\right), 20.9\left(\mathrm{C}-5^{\prime \prime \prime}\right)\right]$, and one epoxy group $\left[\delta_{\mathrm{H}} 3.26\right.$ $\left.(1 \mathrm{H}, \mathrm{m}, \mathrm{H}-4) ; \delta_{\mathrm{C}} 58.2(\mathrm{C}-3), 61.4(\mathrm{C}-4)\right]$. The $1 \mathrm{D}$ and $2 \mathrm{D}$ NMR data of 7 showed similarity to those of $2 \beta, 8$-diangeloyloxy- $3 \beta, 4 \beta$ epoxy-1 $\beta, 10,11$-trihydroxybisabol-7(14)-ene, ${ }^{15}$ which was a bisabolane-type sesquiterpene derived from the roots of Ligularia cymbulifera. The difference between them lies primarily in the positions of an acetoxy group, a (2-methylbutanoyl)oxy group, and an angeloyloxy group, which were deduced from the HMBC correlations of $\mathrm{H}-1 / \mathrm{C}-1^{\prime}, \mathrm{H}-2 / \mathrm{C}-1^{\prime \prime}$, and $\mathrm{H}-8 / \mathrm{C}-1^{\prime \prime \prime}$, respectively.

The relative configuration of the six-membered ring in 7 was established from the ${ }^{1} \mathrm{H}$ NMR coupling constants and the NOESY correlations (Fig. 5). When H-6 is assumed to be $\beta$ oriented, $\mathrm{H}-1$ should be $\beta$-oriented due to the small coupling constant of $\mathrm{H}-1 / \mathrm{H}-6\left(J_{1,6}=1.5 \mathrm{~Hz}\right) . \mathrm{H}-2$ was also determined to be $\beta$-oriented by the NOESY correlation between $\mathrm{H}-2$ and H-6. Considering the fact that the six-membered ring should have a twist-boat conformation because of the epoxy group, $\mathrm{H}-4$ was supposed to have a $\beta$-equatorial position due to the NOESY correlation between $\mathrm{H}-4$ and $\mathrm{H}-6$. $\mathrm{H}-15$ was deduced in $\beta$ oriented position based on the NOESY correlations of $\mathrm{H}-2, \mathrm{H}-4$ / Me-15. Thus, the relative configuration within the cyclohexane ring was established and the structure of 7 was then defined.

Pararunine F (8), a yellow oil, exhibited a molecular formula of $\mathrm{C}_{28} \mathrm{H}_{42} \mathrm{O}_{9}$ as determined by the HRESIMS and ${ }^{13} \mathrm{C}$ NMR data, requiring 8 indices of hydrogen deficiency. The NMR spectral data (Tables 1 and 2) of $\mathbf{8}$ were similar to those of 7, except that a (2-methylbutanoyl)oxy group in 7 was replaced by a (4-methylsenecioyl)oxy group in $\mathbf{8}$, and the angeloyloxy group in $\mathbf{8}$ was attached at $\mathrm{C}-10$ by the HMBC correlations of $\mathrm{H}-10 / \mathrm{C}-\mathrm{1}^{\prime \prime \prime}$. The relative configuration of the six-membered ring in $\mathbf{8}$ was determined using the same methods as that applied for 7 . Thus, the structure of 8 was elucidated as shown.

Pararunine G (9) appeared as a yellow oil. Its molecular formula was established as $\mathrm{C}_{28} \mathrm{H}_{42} \mathrm{O}_{9}$, which was the same as 8 , by the HRESIMS and ${ }^{13} \mathrm{C}$ NMR data, requiring 8 indices of hydrogen deficiency. The NMR spectral data (Tables 1 and 2) of 9 were generally similar to those of $\mathbf{8}$, with the only difference being that the angeloyloxy group in 9 was attached at C-8 by the HMBC correlations of $\mathrm{H}-8 / \mathrm{C}-\mathrm{1}^{\prime \prime \prime}$. The relative configuration of the six-membered ring in $\mathbf{9}$ was established by methods similar to those used for $\mathbf{7}$. Therefore, the structure of $\mathbf{9}$ was deduced as shown.

Pararunine $\mathrm{H}$ (12), a yellow oil, was assigned the molecular formula of $\mathrm{C}_{29} \mathrm{H}_{44} \mathrm{O}_{12}$ with 8 indices of hydrogen deficiency according to the HRESIMS and ${ }^{13} \mathrm{C}$ NMR data. The $1 \mathrm{D}$ NMR data (Tables 1 and 3) of 12 were very similar to those of $4 \alpha$ acetyl-2 $\beta, 5 \alpha, 8$-triisobutyryl-1 $\beta, 3 \alpha, 10,11$-tetrahydroxybisabolene ${ }^{\mathbf{1 6}}$

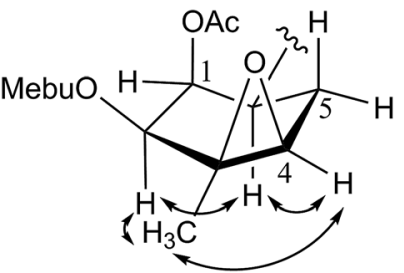

Fig. 5 Key NOESY $(\leftrightarrow)$ correlations of compound 7 . 
Table $3{ }^{1} \mathrm{H}$ NMR data for compounds $12-18(400 \mathrm{MHz}, \mathrm{J}$ in $\mathrm{Hz})$

\begin{tabular}{|c|c|c|c|c|c|c|c|c|}
\hline No. & $12^{b}$ & $13^{b}$ & $14^{b}$ & No. & $15^{a}$ & $16^{a}$ & $17^{a}$ & $18^{a}$ \\
\hline 1 & $5.42 \mathrm{dd}(3.9,2.7)$ & 5.24 overlap & $4.07 \mathrm{~d}(10.9,10.2)$ & 3 & $6.26 \mathrm{~d}(9.5)$ & $6.26 \mathrm{~d}(9.5)$ & $6.26 \mathrm{~d}(9.6)$ & $6.23 \mathrm{~d}(9.5)$ \\
\hline 2 & $4.95 \mathrm{~d}(3.9)$ & $4.90 \mathrm{~d}(3.7)$ & $5.18 \mathrm{~d}(10.2)$ & 4 & $7.63 \mathrm{~d}(9.5)$ & $7.63 \mathrm{~d}(9.5)$ & 7.63 d (9.6) & $7.62 \mathrm{~d}(9.5)$ \\
\hline 5 & $4.60 \mathrm{dd}(11.5,3.0)$ & 4.59 dd $(11.3,2.8)$ & 1.92 overlap & 6 & $6.81 \mathrm{dd}(8.5,2.3)$ & $6.86 \mathrm{dd}(8.6,2.3)$ & $6.82 \mathrm{dd}(8.5,2.4)$ & $6.79 \mathrm{dd}(8.6,2.4)$ \\
\hline 6 & $2.99 \mathrm{dd}(11.5,2.7)$ & $3.02 \mathrm{dd}(11.3,2.6)$ & $\begin{array}{l}2.58 \mathrm{ddd} \\
(11.0,10.9,5.2)\end{array}$ & 8 & $6.79 \mathrm{~d}(2.3)$ & $6.82 \mathrm{~d}(2.3)$ & $6.80 \mathrm{~d}(2.4)$ & $6.74 \mathrm{~d}(2.4)$ \\
\hline 10 & 4.96 overlap & 3.34 overlap & $3.42 \mathrm{~m}$ & $4^{\prime}$ & $3.45 \mathrm{~s}$ & $3.73 \mathrm{~s}$ & $3.67 \mathrm{~s}$ & $3.41 \mathrm{~s}$ \\
\hline 12 & $1.11 \mathrm{~s}$ & $1.13 \mathrm{~s}$ & $1.16 \mathrm{~s}$ & $6^{\prime}$ & $2.47 \mathrm{~d}(6.9)$ & $3.52 \mathrm{~s}$ & $2.74 \mathrm{~d}(4.4)$ & $6.31 \mathrm{~s}$ \\
\hline 13 & $1.11 \mathrm{~s}$ & $1.11 \mathrm{~s}$ & $1.17 \mathrm{~s}$ & $7^{\prime}$ & $2.20 \mathrm{~m}$ & & & \\
\hline 14 & $5.16 \mathrm{~s}, 5.19 \mathrm{~s}$ & $5.24 \mathrm{~s}, 5.43 \mathrm{~s}$ & $5.07 \mathrm{~s}, 5.17 \mathrm{~s}$ & $8^{\prime}$ & $0.95 \mathrm{~d}(4.5)$ & $1.40 \mathrm{~s}$ & $1.30 \mathrm{~s}$ & $2.19 \mathrm{~s}$ \\
\hline 15 & $1.11 \mathrm{~s}$ & $1.11 \mathrm{~s}$ & $1.23 \mathrm{~s}$ & $9^{\prime}$ & $0.97 \mathrm{~d}(4.5)$ & $1.49 \mathrm{~s}$ & $1.28 \mathrm{~s}$ & $1.95 \mathrm{~s}$ \\
\hline $3^{\prime \prime}$ & & & 6.14 qq $(7.2,1.3)$ & & & & & \\
\hline $4^{\prime \prime}$ & & & $1.98 \mathrm{dq}(7.2,1.3)$ & & & & & \\
\hline $5^{\prime \prime}$ & & & $1.93 \mathrm{q}(1.3)$ & & & & & \\
\hline $2^{\prime \prime \prime}$ & $2.06 \mathrm{~s}$ & $2.03 \mathrm{~s}$ & & & & & & \\
\hline $3^{\prime \prime \prime \prime \prime}$ & $6.11 \mathrm{qq}(7.3,1.4)$ & $6.16 \mathrm{qq}(7.5,1.4)$ & & & & & & \\
\hline $4^{\prime \prime \prime \prime \prime}$ & $1.98 \mathrm{dq}(7.3,1.4)$ & $2.00 \mathrm{dq}(7.5,1.4)$ & & & & & & \\
\hline $5^{\prime \prime \prime \prime}$ & $1.91 \mathrm{q}(1.4)$ & $1.89 \mathrm{q}(1.4)$ & & & & & & \\
\hline
\end{tabular}

except for the different substituent groups. Accordingly, 12 was presented to be a bisabolane-type sesquiterpenoid with two acetoxy and two angeloyloxy groups, the positions of which were determined by the HMBC correlations of $\mathrm{H}-1 / \mathrm{C}-1^{\prime}, \mathrm{H}-2 / \mathrm{C}-1^{\prime \prime}$, $\mathrm{H}-4 / \mathrm{C}-1^{\prime \prime \prime}$, and $\mathrm{H}-10 / \mathrm{C}-1^{\prime \prime \prime \prime}$, respectively.

The relative configuration of the six-membered ring in $\mathbf{1 2}$ was identical to that of $4 \alpha$-acetyl-2 $\beta, 5 \alpha, 8$-triisobutyryl$1 \beta, 3 \alpha, 10,11$-tetrahydroxybisabolene on the basis of its ${ }^{1} \mathrm{H}$ NMR coupling constants and NOESY correlations. When $\mathrm{H}-6$ is assumed to be in a $\beta$-orientation, $\mathrm{H}-1$ should be $\beta$-equatorial due to the small coupling constant of $\mathrm{H}-1 / \mathrm{H}-6\left(J_{1,6}=2.7 \mathrm{~Hz}\right), \mathrm{H}-$ 5 must be $\alpha$-axial due to the large coupling constant of $\mathrm{H}-5 / \mathrm{H}-6$ $\left(J_{5,6}=11.5 \mathrm{~Hz}\right)$, and $\mathrm{H}-4$ should be $\alpha$-equatorial due to the small coupling constant of $\mathrm{H}-4 / \mathrm{H}-5\left(J_{4,5}=3.0 \mathrm{~Hz}\right)$. The NOESY correlation of $\mathrm{H}-2 / \mathrm{H}-6$ indicated a $\beta$-orientation for $\mathrm{H}-2.12$ was therefore elucidated as shown.

Pararunine I (13), obtained as a yellow oil, was designated with a molecular formula of $\mathrm{C}_{29} \mathrm{H}_{44} \mathrm{O}_{12}$ with 8 indices of hydrogen deficiency on the basis of its HRESIMS and ${ }^{13} \mathrm{C}$ NMR data. The NMR data (Tables 1 and 3) of $\mathbf{1 3}$ were similar to those of 12, indicating that $\mathbf{1 3}$ was also a bisabolane-type sesquiterpenoid with two acetoxy and two angeloyloxy groups. The only difference between the two compounds was the position of an angeloyloxy group, which was attached at C-8 in 13 instead of $\mathrm{C}-10$ in 12 by the HMBC correlations of $\mathrm{H}-8 / \mathrm{C}-1^{\prime \prime \prime \prime}$. The ${ }^{1} \mathrm{H}$ NMR coupling constants and NOESY correlations of 13 showed that its relative configuration was identical to that of $\mathbf{1 2}$. Thus, the structure of $\mathbf{1 3}$ was constructed as shown.
Pararunine J (14), a yellow oil, exhibited a molecular formula of $\mathrm{C}_{25} \mathrm{H}_{40} \mathrm{O}_{9}$ as determined by the HRESIMS and ${ }^{13} \mathrm{C}$ NMR data, requiring 6 indices of hydrogen deficiency. Analysis of its 1D and 2D NMR data revealed that $\mathbf{1 4}$ was also a bisabolane-type sesquiterpenoid with two angeloyloxy groups, which were attached to $\mathrm{C}-2$ and $\mathrm{C}-8$, respectively, according to the $\mathrm{HMBC}$ correlations. The relative configuration of the six-membered ring system in $\mathbf{1 4}$ could be proposed by analysis of ${ }^{1} \mathrm{H}$ NMR coupling constants and NOESY data. H-6 is assumed to be $\beta$ oriented, then $\mathrm{H}-1$ should be $\alpha$-axial, and $\mathrm{H}-2$ should be $\beta$-axial based on the large coupling constants of $\mathrm{H}-1 / \mathrm{H}-6\left(J_{1,6}=10.9\right.$ $\mathrm{Hz})$, and $\mathrm{H}-1 / \mathrm{H}-2\left(J_{1,2}=10.2 \mathrm{~Hz}\right) . \mathrm{H}-4$ must be $\alpha$-equatorial due to the small coupling constants of $\mathrm{H}-4 / \mathrm{H}-5\left(J_{4,5}=1.7,3.5 \mathrm{~Hz}\right)$. Therefore, the structure of $\mathbf{1 4}$ was defined as shown.

The structures of the known compounds $\mathbf{1 0}$ and $\mathbf{1 1}$ were respectively confirmed as $1 \alpha$-acetoxy- $2 \alpha, 8$-diangeloyloxy- $3 \alpha, 4 \alpha$ epoxy-10,11-dihydroxybisabol-7(14)-ene, ${ }^{17}$ and $1 \alpha$-acetoxy- $2 \alpha, 10$ diangeloyloxy-3 $\alpha, 4 \alpha$-epoxy-8,11-dihydroxybisabol-7(14)-ene, ${ }^{18}$ by comparing their spectroscopic data with published literature data.

\section{Monoterpenoid coumarins}

An examination of the ${ }^{1} \mathrm{H}$ NMR data (Table 3 ) in the aromatic region of compounds 15-18 revealed a pair of doublets at $c a$. 6.26, 7.63 (each $1 \mathrm{H}, \mathrm{d}, J=9.5 \mathrm{~Hz}$ ) and an ABX pattern signals at ca. $6.79(1 \mathrm{H}, \mathrm{d}, J=2.3 \mathrm{~Hz}), 6.82(1 \mathrm{H}, \mathrm{dd}, J=8.5,2.3 \mathrm{~Hz})$, and $7.37(1 \mathrm{H}, \mathrm{d}, J=8.5 \mathrm{~Hz})$ corresponding to 7 -substituted coumarin moieties. Accordingly, the maximal absorption of the 
UV spectra ( $c a .258$ and $320 \mathrm{~nm}$ ) of compounds 15-18 also indicated the presences of 7-oxygenated coumarin skeletons. Besides, the combined analysis of 2D NMR of 15-18 revealed the structures of their different side chains to be similar acyclic monoterpenoid moieties. The experimental electronic circular dichroism (ECD) data of 15-18 were collected to determine their absolute configurations, but unfortunately, no valuable calculated ECD data was obtained due to the flexible linear side chain of each compound. In addition, as far as we are aware, no effective method has been established to determine the absolute configurations of this type of monoterpenoid coumarins.

Pararubcoumarin A (15) was obtained as a yellow oil, and the molecular formula, $\mathrm{C}_{19} \mathrm{H}_{22} \mathrm{O}_{5}$, was determined based on its NMR data (Tables 1 and 3) and the HRESIMS analysis, which indicated 11 indices of hydrogen deficiency. Apart from the 7-substituted coumarin moiety, there were ten more carbons for a side chain, which included one ketone carbonyl group $\left[\delta_{\mathrm{C}}\right.$

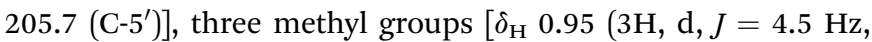
$\left.\mathrm{H}-8^{\prime}\right), 0.97\left(3 \mathrm{H}, \mathrm{d}, J=4.5 \mathrm{~Hz}, \mathrm{H}-9^{\prime}\right), 1.52\left(3 \mathrm{H}, \mathrm{s}, \mathrm{H}-10^{\prime}\right) ; \delta_{\mathrm{C}} 22.8(\mathrm{C}-$ $\left.\left.8^{\prime}\right), 22.8\left(\mathrm{C}-9^{\prime}\right), 22.7\left(\mathrm{C}-10^{\prime}\right)\right]$, three methylene groups $\left[\delta_{\mathrm{H}} 4.13\right.$ $\left(2 \mathrm{H}, \mathrm{m}, \mathrm{H}-1^{\prime}\right), 2.02\left(2 \mathrm{H}, \mathrm{s}, \mathrm{H}-2^{\prime}\right), 2.47\left(2 \mathrm{H}, \mathrm{d}, J=6.9 \mathrm{~Hz}, \mathrm{H}-6^{\prime}\right) ; \delta_{\mathrm{C}}$ $\left.65.3\left(\mathrm{C}-1^{\prime}\right), 31.5\left(\mathrm{C}-2^{\prime}\right), 50.4\left(\mathrm{C}-6^{\prime}\right)\right]$, two methine groups $\left[\delta_{\mathrm{H}} 3.45\right.$ $\left.\left(1 \mathrm{H}, \mathrm{s}, \mathrm{H}-4^{\prime}\right), 2.20\left(1 \mathrm{H}, \mathrm{s}, \mathrm{H}-7^{\prime}\right) ; \delta_{\mathrm{C}} 65.5\left(\mathrm{C}-4^{\prime}\right), 24.6\left(\mathrm{C}-7^{\prime}\right)\right]$, and a quaternary carbon $\left[\delta_{\mathrm{C}} 62.2\left(\mathrm{C}-3^{\prime}\right)\right]$. Analysis of its ${ }^{1} \mathrm{H}-{ }^{1} \mathrm{H}$ COSY spectrum revealed the assignment of two spin systems, $-\mathrm{CH}_{2}(\mathrm{H}-$ $\left.1^{\prime}\right)-\mathrm{CH}_{2}\left(\mathrm{H}-2^{\prime}\right)-$ and $-\mathrm{CH}_{2}\left(\mathrm{H}-6^{\prime}\right)-\mathrm{CH}\left(\mathrm{H}-7^{\prime}\right)-\mathrm{CH}_{3}\left(\mathrm{H}-8^{\prime}\right)-\mathrm{CH}_{3}\left(\mathrm{H}-9^{\prime}\right)-$ (Fig. 5), which were connected to form an acyclic monoterpenoid moiety by the $\mathrm{HMBC}$ correlations (Fig. 6) of $\mathrm{H}-1^{\prime}, \mathrm{H}-4^{\prime}$ / $\mathrm{C}-3^{\prime} ; \mathrm{H}-10^{\prime} / \mathrm{C}-2^{\prime} ; \mathrm{H}-10^{\prime} / \mathrm{C}-4^{\prime}$; and $\mathrm{H}-4^{\prime}, \mathrm{H}-6^{\prime} / \mathrm{C}-5^{\prime}$. Furthermore, to accommodate 9 indices of hydrogen deficiency (the 7substituted coumarin moiety and one ketone carbonyl group
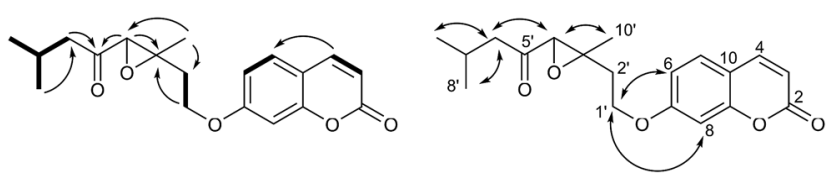

Fig. 6 Key $\operatorname{HMBC}(\rightarrow),{ }^{1} \mathrm{H}-{ }^{1} \mathrm{H}$ COSY (thick lines) and $\operatorname{NOESY}(\leftrightarrow)$ correlations of compound 15. accounted for 8 of those), compound 15 was proposed to have an epoxy group $\left[\delta_{\mathrm{H}} 3.45\left(1 \mathrm{H}, \mathrm{s}, \mathrm{H}-4^{\prime}\right) ; \delta_{\mathrm{C}} 62.2\left(\mathrm{C}-3^{\prime}\right), 65.5\left(\mathrm{C}-4^{\prime}\right)\right]$. Thus, the structure of 15 was determined as 7-[( $3^{\prime}, 7^{\prime}$-dimethylocta- $3^{\prime}, 4^{\prime}$ epoxy-5'-one)oxy]coumarin, named pararubcoumarin A.

Pararubcoumarin $\mathrm{B}$ (16), isolated as a yellow oil, has the molecular formula of $\mathrm{C}_{19} \mathrm{H}_{20} \mathrm{O}_{6}$ as determined by the HRESIMS and ${ }^{13} \mathrm{C}$ NMR data, suggesting 10 indices of hydrogen deficiency. The $1 \mathrm{D}$ NMR data (Tables 1 and 3) of $\mathbf{1 6}$ were similar to those of 15, except for the presence of an extra epoxy group $\left[\delta_{\mathrm{H}}\right.$ $\left.3.52\left(1 \mathrm{H}, \mathrm{s}, \mathrm{H}-6^{\prime}\right) ; \delta_{\mathrm{C}} 65.1\left(\mathrm{C}-6^{\prime}\right), 62.1\left(\mathrm{C}-7^{\prime}\right)\right]$, the position of which was determined by the HMBC correlations of $\mathrm{H}-6^{\prime} / \mathrm{C}-5^{\prime}$ and $H-8^{\prime} / C-6^{\prime}$. Thus, the structure of $\mathbf{1 6}$ was defined as shown, given the name pararubcoumarin $\mathrm{B}$.

Pararubcoumarin $\mathrm{C}$ (17), a yellow oil, has the molecular formula of $\mathrm{C}_{20} \mathrm{H}_{24} \mathrm{O}_{6}$ as established by the ${ }^{13} \mathrm{C}$ NMR and HRESIMS data, corresponding to 9 indices of hydrogen deficiency. The NMR data (Tables 1 and 3) of $\mathbf{1 7}$ also resembled those of $\mathbf{1 5}$, with the only difference being the presence of an extra methoxy group at $\mathrm{C}-\mathbf{7}^{\prime}$ in $\mathbf{1 7}$, which was confirmed by the HMBC correlation of $\mathrm{MeO}-\mathbf{7}^{\prime} / \mathrm{C}-\mathbf{7}^{\prime}$. Thus, the structure of $\mathbf{1 7}$ was determined as shown, named pararubcoumarin $\mathrm{C}$.

Pararubcoumarin D (18) was isolated as a yellow oil. Its molecular formula was established as $\mathrm{C}_{19} \mathrm{H}_{20} \mathrm{O}_{5}$, with 10 indices of hydrogen deficiency by the HRESIMS and ${ }^{13} \mathrm{C}$ NMR data. Comparison of the NMR data (Tables 1 and 3) of $\mathbf{1 8}$ with those of 15 displayed the major difference being the presence of an extra $\Delta^{6^{\prime}, 7^{\prime}}$ double bond in $\mathbf{1 8}$, which was confirmed by the HMBC correlations $\mathrm{H}-8^{\prime}, \mathrm{H}-4^{\prime} / \mathrm{C}-6^{\prime}$, given the name pararubcoumarin D.

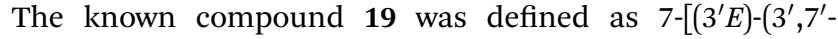
dimethylocta-3' ${ }^{\prime}, 6^{\prime}$-dien- $5^{\prime}$-one)oxy] coumarin, ${ }^{19}$ by comparing its spectroscopic data with published literature data.

It was reported that some highly oxygenated bisabolane-type sesquiterpenoids possess potential antimicrobial or cytotoxic activities ${ }^{\mathbf{1 5 , 2 0 , 2 1}}$ and some highly oxygenated oplopane-type sesquiterpenoids show varying degrees of cytotoxic activity. ${ }^{22}$ Therefore, all isolates were evaluated for their in vitro cytotoxicity against B16 mouse melanoma, HepG2 human hepatocellular carcinoma, and MCF7 human breast adenocarcinoma cell

Table 4 Cytotoxicity of compounds 1-19 against B16, HepG2 and MCF7 cell lines ${ }^{a}$

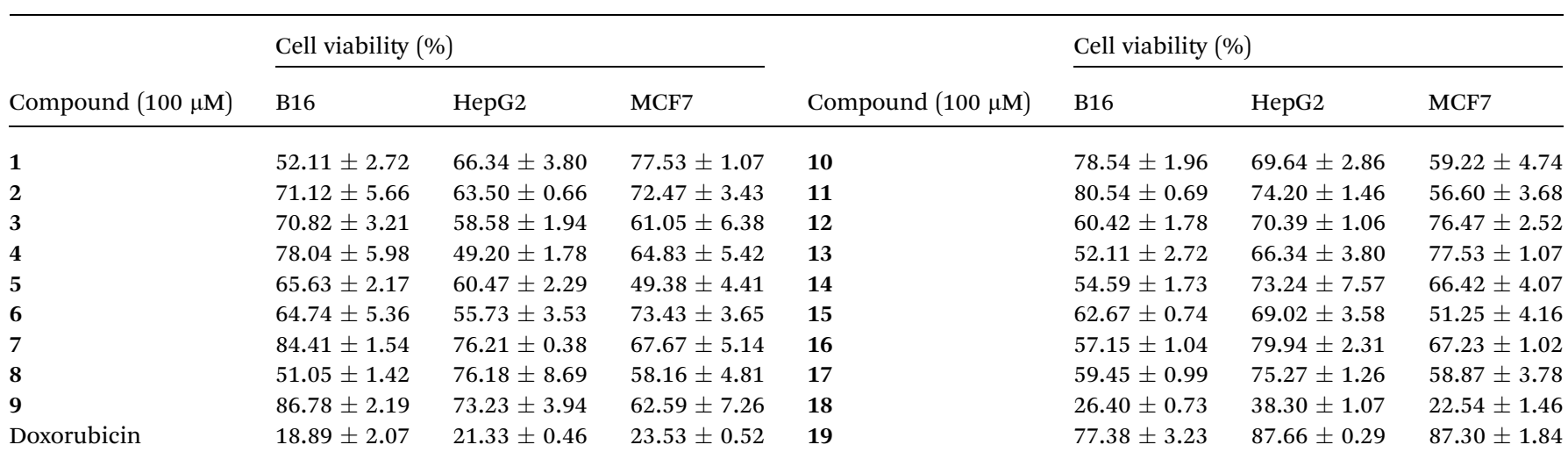

${ }^{a}$ The data (cell viability, measured by the MTT assay) were normalized and expressed as a percentage of the control group, which is set to $100 \%$. Doxorubicin was used as a positive control. 
lines, as well as their antimicrobial effects against Staphylococcus aureus, Escherichia coli, and Monilia albicans. However, none of them showed any appreciable cytotoxic (Table 4) or antimicrobial effect.

\section{Conclusions}

Previous phytochemical research on Parasenecio demonstrated that eremophilane-type sesquiterpenoids accounted for the characteristic constituents of this genus. ${ }^{3-8}$ However, in our previous $^{11}$ and present studies on $P$. rubescens, with the identifications of nearly three dozen bisabolane-type sesquiterpenoids, not a single one of eremophilane was found. Also it is noteworthy that compounds isolated form P. rubescens tend to be highly oxygenated. Our current research indicates that highly oxygenated bisabolane-type and oplopane-type sesquiterpenoids, together with monoterpenoid coumarins, may play important roles in the chemotaxonomic significance of $P$. rubescens as well as the genus Parasenecio.

\section{Experimental section}

\section{General experimental procedures}

Optical rotations were measured by a PerkinElmer model 341 polarimeter. UV spectra were obtained on a Jasco J-810 spectropolarimeter. IR spectra were recorded on a Bruker VERTEX 70 FT-IR microscopic spectroscopy. NMR experiments were carried out on a Bruker-AM-400 spectrometer. X-ray crystallographic analysis was collected on a Bruker APEX DUO diffractometer using $\mathrm{Cu} \mathrm{K} \alpha$ radiation. HRESIMS spectra were obtained from a Thermo Scientific LTQ-Orbitrap XL mass spectrometer. Column silica gel (200-300 or 300-400 mesh; Qingdao Marine Chemical Inc.), Sephadex LH-20 gel (GE Healthcare), and MCI gel (CHP20P, 75-150 $\mu \mathrm{m}$; Mitsubishi Chemical Industries Ltd.) were used for column chromatography. HPLC was conducted on an Agilent 1260 system using YMC-Pack ODS-A HPLC column $(250 \mathrm{~mm} \times 10 \mathrm{~mm}$ i.d. $)$ and YMC-Pack SIL-06 HPLC column $(250 \mathrm{~mm} \times 10 \mathrm{~mm}$ i.d. $)$.

\section{Plant material}

Whole plants of $P$. rubescens were collected in the Lushan mountains of Jiangxi Province, P. R. China, in September 2012. The plant was identified by research scientist Bei-Li Huang (Lushan Botanical Garden). A voucher specimen (ID 20120901) was deposited in the Herbarium of Materia Medica, Faculty of Pharmacy, Tongji Medical College of Huazhong University of Science and Technology, Wuhan, P. R. China.

\section{Extraction and isolation}

The air-dried whole plants of $P$. rubescens $(18.4 \mathrm{~kg})$ were extracted with $90 \%$ acetone $(5 \times 50 \mathrm{~L})$ at room temperature and concentrated in vacuo to give $10 \mathrm{~L}$ of extract. The solution was sequentially partitioned with PE and EtOAc. The EtOAc-soluble fraction (180.0 g) was subjected to a silica gel column, eluting with PE/acetone (20:1-1: 10 step gradient elution), to obtain five major fractions (A-E). Fraction A (35.0 g) was decolored on an MCI gel column $\left(\mathrm{MeOH} / \mathrm{H}_{2} \mathrm{O}\right.$, from 75 to $\left.100 \%\right)$ to afford three fractions, A1-A3, which were chromatographed on a Sephadex LH-20 column (MeOH) separately. Fraction A1.2 was subjected to silica gel column (PE/acetone, from $20: 1$ to $1: 10$ ) and semipreparative $\mathrm{HPLC}\left(\mathrm{MeOH} / \mathrm{H}_{2} \mathrm{O}, 7: 3\right)$ to yield $3(5.7 \mathrm{mg}$, $\left.t_{\mathrm{R}} 28.1 \mathrm{~min}\right)$. Fraction A2.2 was subjected to semipreparative $\mathrm{HPLC}\left(\mathrm{MeOH} / \mathrm{H}_{2} \mathrm{O}, 7: 3\right)$ to yield $15\left(5.8 \mathrm{mg}, t_{\mathrm{R}} 27.2 \mathrm{~min}\right)$ and 19 (6.1 $\mathrm{mg}, t_{\mathrm{R}} 31.6 \mathrm{~min}$ ), while A2.3 was also subjected to semipreparative $\mathrm{HPLC}\left(\mathrm{MeOH} / \mathrm{H}_{2} \mathrm{O}, 7: 3\right)$ to yield $16\left(1.5 \mathrm{mg}, t_{\mathrm{R}} 30.5\right.$ $\mathrm{min}), 17\left(2.2 \mathrm{mg}, t_{\mathrm{R}} 40.7 \mathrm{~min}\right)$, and 18 (4.3 $\left.\mathrm{mg}, t_{\mathrm{R}} 35.3 \mathrm{~min}\right)$. Fraction A3.1 was separated on ODS silica gel column (MeOH/ $\mathrm{H}_{2} \mathrm{O}$, from 30 to $\left.100 \%\right)$ and semipreparative $\mathrm{HPLC}\left(\mathrm{MeOH} / \mathrm{H}_{2} \mathrm{O}\right.$, $7: 3)$ to yield $11\left(5.7 \mathrm{mg}, t_{\mathrm{R}} 41.8 \mathrm{~min}\right)$, and similarly, fraction A3.2 was purified in the same way as A3.1 to yield $1\left(5.2 \mathrm{mg}, t_{\mathrm{R}}\right.$ $38.8 \mathrm{~min}), 2$ (3.7 mg, $\left.t_{\mathrm{R}} 45.8 \mathrm{~min}\right)$, and 4 (19.0 $\left.\mathrm{mg}, t_{\mathrm{R}} 31.2 \mathrm{~min}\right)$. Fraction B $(62.3 \mathrm{~g})$ was decolored on an MCI gel column (MeOH/ $\mathrm{H}_{2} \mathrm{O}$, from $75 \%$ to $100 \%$ ) to afford three fractions, B1-B3. Fraction B3 was fractionated using a Sephadex LH-20 column $(\mathrm{MeOH})$ to produce four subfractions, B3.1-B3.4. Fraction B3.1 was further resolved by ODS silica gel $\left(\mathrm{MeOH} / \mathrm{H}_{2} \mathrm{O}\right.$, from 30 to $100 \%)$, semipreparative HPLC $\left(\mathrm{MeOH} / \mathrm{H}_{2} \mathrm{O}, 7: 3\right)$, and normal phase HPLC ( $n$-hexane/2-propanol, $15: 1$ ) columns to yield 12 (4.8 mg, $\left.t_{\mathrm{R}} 17.3 \mathrm{~min}\right), 13$ (4.4 mg, $\left.t_{\mathrm{R}} 15.4 \mathrm{~min}\right)$, and $14\left(2.0 \mathrm{mg}, t_{\mathrm{R}}\right.$ $21.5 \mathrm{~min})$. Using the same methods applied in B3.1, $5\left(1.0 \mathrm{mg}, t_{\mathrm{R}}\right.$ $17.8 \mathrm{~min}), 6$ (2.9 mg, $\left.t_{\mathrm{R}} 15.8 \mathrm{~min}\right), 7$ (4.8 mg, $\left.t_{\mathrm{R}} 23.6 \mathrm{~min}\right)$, and 9 $\left(4.4 \mathrm{mg}, t_{\mathrm{R}} 20.4 \mathrm{~min}\right)$ were afforded from B3.2, and $8\left(3.7 \mathrm{mg}, t_{\mathrm{R}}\right.$ $21.7 \mathrm{~min}), 10\left(18.0 \mathrm{mg}, t_{\mathrm{R}} 16.3 \mathrm{~min}\right.$ ) were obtained from B3.3.

Pararunine A (1). Colorless crystals (MeOH); mp 147-149 ${ }^{\circ} \mathrm{C}$; $[\alpha]_{\mathrm{D}}^{20}+31\left(c\right.$ 0.11, $\left.\mathrm{CH}_{3} \mathrm{OH}\right) ; \mathrm{UV}\left(\mathrm{CH}_{3} \mathrm{OH}\right) \lambda_{\max }(\log \varepsilon) 215(4.40) \mathrm{nm}$; IR (KBr) $\nu_{\max } 2969,2937,2877,1738,1655 \mathrm{~cm}^{-1} ;{ }^{1} \mathrm{H}$ and ${ }^{13} \mathrm{C}$ NMR data see Tables 1 and 2; HRESIMS $m / z 727.3301[\mathrm{M}+\mathrm{Na}]^{+}$(calcd for $\left.\mathrm{C}_{37} \mathrm{H}_{52} \mathrm{O}_{13} \mathrm{Na}, 727.3306\right)$. Crystal data: $\mathrm{C}_{37} \mathrm{H}_{52} \mathrm{O}_{13}, M_{\mathrm{W}}=$ 704.79, orthorhombic, space group $P 2{ }_{1} 2_{1} 2_{1}, a=12.2069$ (2) $\AA$, $b=$

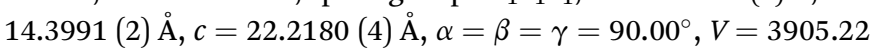
(11) $\AA^{3}, Z=4, \rho$ (calcd) $=1.199 \mathrm{~g} \mathrm{~cm}^{-3}$, and $\mu(\mathrm{Cu} \mathrm{K} \alpha)=0.749$ $\mathrm{mm}^{-1}$; reflections collected 53820 , independent reflections 6906; final $R$ indices $[I>2 \sigma(I)] R_{1}=0.0520, \mathrm{w} R_{2}=0.1657 ; R$ indices (all data) $R=0.0532, \mathrm{w} R_{2}=0.1686$; largest diff. peak and hole 0.494 and -0.290 e $\AA^{-3}$; flack parameter 0.15 (18). Reflections collected: 53820 (CCDC No. 1472359). $\dagger$

Pararunine B (2). Yellow oil; $[\alpha]_{\mathrm{D}}^{20}+36\left(c\right.$ 0.08, $\left.\mathrm{CH}_{3} \mathrm{OH}\right)$; UV $\left(\mathrm{CH}_{3} \mathrm{OH}\right) \lambda_{\max }(\log \varepsilon) 215$ (4.38); IR (KBr) $\nu_{\max } 2974,2938,2879$, 1744, $1657 \mathrm{~cm}^{-1} ;{ }^{1} \mathrm{H}$ and ${ }^{13} \mathrm{C}$ NMR data see Tables 1 and 2; HRESIMS $m / z$ 687.2988 $[\mathrm{M}+\mathrm{Na}]^{+}$(calcd for $\mathrm{C}_{34} \mathrm{H}_{48} \mathrm{O}_{13} \mathrm{Na}$, 687.2993).

Pararunine C (5). Yellow oil; $[\alpha]_{\mathrm{D}}^{20}-31\left(c 0.02, \mathrm{CH}_{3} \mathrm{OH}\right)$; UV $\left(\mathrm{CH}_{3} \mathrm{OH}\right) \lambda_{\max }(\log \varepsilon) 216$ (4.21) nm; IR (KBr) $\nu_{\max } 3508,1743$, $1648 \mathrm{~cm}^{-1} ;{ }^{1} \mathrm{H}$ and ${ }^{13} \mathrm{C}$ NMR data see Tables 1 and 2; HRESIMS $m / z 489.2454[\mathrm{M}+\mathrm{Na}]^{+}$(calcd for $\mathrm{C}_{25} \mathrm{H}_{38} \mathrm{O}_{8} \mathrm{Na}, 489.2464$ ).

Pararunine D (6). Yellow oil; $[\alpha]_{\mathrm{D}}^{20}-26\left(c 0.06, \mathrm{CH}_{3} \mathrm{OH}\right)$; UV $\left(\mathrm{CH}_{3} \mathrm{OH}\right) \lambda_{\max }(\log \varepsilon) 217$ (4.40) nm; IR (KBr) $\nu_{\max } 3476,1718$, $1647 \mathrm{~cm}^{-1}$; ${ }^{1} \mathrm{H}$ and ${ }^{13} \mathrm{C}$ NMR data see Tables 1 and 2; HRESIMS $m / z 531.2570[\mathrm{M}+\mathrm{Na}]^{+}$(calcd for $\mathrm{C}_{27} \mathrm{H}_{40} \mathrm{O}_{9} \mathrm{Na}, 531.2563$ ).

Pararunine E (7). Yellow oil; $[\alpha]_{\mathrm{D}}^{20}-37\left(c 0.31, \mathrm{CH}_{3} \mathrm{OH}\right) ; \mathrm{UV}$ $\left(\mathrm{CH}_{3} \mathrm{OH}\right) \lambda_{\max }(\log \varepsilon) 216$ (4.21) nm; IR (KBr) $\nu_{\max } 3508,1743$, $1648 \mathrm{~cm}^{-1} ;{ }^{1} \mathrm{H}$ and ${ }^{13} \mathrm{C}$ NMR data see Tables 1 and 2; HRESIMS $m / z 533.2722[\mathrm{M}+\mathrm{Na}]^{+}$(calcd for $\mathrm{C}_{27} \mathrm{H}_{42} \mathrm{O}_{9} \mathrm{Na}, 533.2727$ ). 
Pararunine F (8). Yellow oil; $[\alpha]_{\mathrm{D}}^{20}-23\left(c 0.09, \mathrm{CH}_{3} \mathrm{OH}\right)$; UV $\left(\mathrm{CH}_{3} \mathrm{OH}\right) \lambda_{\max }(\log \varepsilon) 217$ (4.40) nm; IR (KBr) $\nu_{\max } 3476,1718$, $1647 \mathrm{~cm}^{-1} ;{ }^{1} \mathrm{H}$ and ${ }^{13} \mathrm{C}$ NMR data see Tables 1 and 2; HRESIMS $m / z 545.2722[\mathrm{M}+\mathrm{Na}]^{+}$(calcd for $\mathrm{C}_{28} \mathrm{H}_{42} \mathrm{O}_{9} \mathrm{Na}, 545.2727$ ).

Pararunine G (9). Yellow oil; $[\alpha]_{\mathrm{D}}^{20}-61\left(c 0.29, \mathrm{CH}_{3} \mathrm{OH}\right)$; UV $\left(\mathrm{CH}_{3} \mathrm{OH}\right) \lambda_{\max }(\log \varepsilon) 218$ (4.42) nm; IR (KBr) $\nu_{\max } 3501,1744$, 1719, $1648 \mathrm{~cm}^{-1} ;{ }^{1} \mathrm{H}$ and ${ }^{13} \mathrm{C}$ NMR data see Tables 1 and 2; HRESIMS $m / z$ 545.2723 $[\mathrm{M}+\mathrm{Na}]^{+}$(calcd for $\mathrm{C}_{28} \mathrm{H}_{42} \mathrm{O}_{9} \mathrm{Na}$, 545.2727).

Pararunine $\mathbf{H}$ (12). Yellow oil; $[\alpha]_{\mathrm{D}}^{20}-23\left(c 0.12, \mathrm{CH}_{3} \mathrm{OH}\right)$; UV $\left(\mathrm{CH}_{3} \mathrm{OH}\right) \lambda_{\max }(\log \varepsilon) 216$ (4.36) nm; IR (KBr) $\nu_{\max } 3459,1720$, $1648 \mathrm{~cm}^{-1}$; ${ }^{1} \mathrm{H}$ and ${ }^{13} \mathrm{C}$ NMR data see Tables 1 and 3; HRESIMS $m / z$ 607.2724 $[\mathrm{M}+\mathrm{Na}]^{+}$(calcd for $\mathrm{C}_{29} \mathrm{H}_{44} \mathrm{O}_{12} \mathrm{Na}, 607.2730$ ).

Pararunine I (13). Yellow oil; $[\alpha]_{\mathrm{D}}^{20}-29\left(c 0.11, \mathrm{CH}_{3} \mathrm{OH}\right)$; UV $\left(\mathrm{CH}_{3} \mathrm{OH}\right) \lambda_{\max }(\log \varepsilon) 216$ (4.36) nm; IR (KBr) $\nu_{\max } 3444,1747$, 1721, $1649 \mathrm{~cm}^{-1} ;{ }^{1} \mathrm{H}$ and ${ }^{13} \mathrm{C}$ NMR data see Tables 1 and 3; HRESIMS $m / z$ 607.2726 $[\mathrm{M}+\mathrm{Na}]^{+}$(calcd for $\mathrm{C}_{29} \mathrm{H}_{44} \mathrm{O}_{12} \mathrm{Na}$, 607.2730).

Pararunine J (14). Yellow oil; $[\alpha]_{\mathrm{D}}^{20}-36\left(c\right.$ 0.05, $\left.\mathrm{CH}_{3} \mathrm{OH}\right)$; UV $\left(\mathrm{CH}_{3} \mathrm{OH}\right) \lambda_{\max }(\log \varepsilon) 215$ (4.25) nm; IR (KBr) $\nu_{\max } 3408,1700$, $1647 \mathrm{~cm}^{-1} ;{ }^{1} \mathrm{H}$ and ${ }^{13} \mathrm{C}$ NMR data see Tables 1 and 3; HRESIMS $m / z 507.2562[\mathrm{M}+\mathrm{Na}]^{+}$(calcd for $\mathrm{C}_{28} \mathrm{H}_{42} \mathrm{O}_{9} \mathrm{Na}, 507.2570$ ).

Pararubcoumarin A (15). Yellow oil; $[\alpha]_{\mathrm{D}}^{25}-28$ (c 0.12, $\left.\mathrm{CH}_{3} \mathrm{OH}\right)$; UV $\left(\mathrm{CH}_{3} \mathrm{OH}\right) \lambda_{\max }(\log \varepsilon) 320$ (4.19) nm; IR (KBr) $\nu_{\max }$ 1732, $1614 \mathrm{~cm}^{-1} ;{ }^{1} \mathrm{H}$ and ${ }^{13} \mathrm{C}$ NMR data see Tables 1 and 3; HRESIMS $m / z$ 353.1357 $[\mathrm{M}+\mathrm{Na}]^{+}$(calcd for $\mathrm{C}_{19} \mathrm{H}_{22} \mathrm{O}_{5} \mathrm{Na}$, 353.1365).

Pararubcoumarin B (16). Yellow oil; $[\alpha]_{\mathrm{D}}^{20}-20\left(c 0.03, \mathrm{CH}_{3} \mathrm{OH}\right)$; $\mathrm{UV}\left(\mathrm{CH}_{3} \mathrm{OH}\right) \lambda_{\max }(\log \varepsilon) 320$ (3.88) nm; IR (KBr) $\nu_{\max } 1728,1614$ $\mathrm{cm}^{-1} ;{ }^{1} \mathrm{H}$ and ${ }^{13} \mathrm{C}$ NMR data see Tables 1 and 3; HRESIMS $\mathrm{m} / \mathrm{z}$ $367.1145[\mathrm{M}+\mathrm{Na}]^{+}$(calcd for $\mathrm{C}_{19} \mathrm{H}_{20} \mathrm{O}_{6} \mathrm{Na}, 367.1158$ ).

Pararubcoumarin $\mathrm{C}$ (17). Yellow oil; $[\alpha]_{\mathrm{D}}^{20}-20$ (c 0.07, $\left.\mathrm{CH}_{3} \mathrm{OH}\right)$; UV $\left(\mathrm{CH}_{3} \mathrm{OH}\right) \lambda_{\max }(\log \varepsilon) 320$ (4.05) nm; IR (KBr) $\nu_{\max }$ 1733, $1614 \mathrm{~cm}^{-1} ;{ }^{1} \mathrm{H}$ and ${ }^{13} \mathrm{C}$ NMR data see Tables 1 and 3; HRESIMS $m / z$ 383.1460 $[\mathrm{M}+\mathrm{Na}]^{+}$(calcd for $\mathrm{C}_{20} \mathrm{H}_{24} \mathrm{O}_{6} \mathrm{Na}$, 383.1470).

Pararubcoumarin D (18). Yellow oil; $[\alpha]_{\mathrm{D}}^{20}-58$ (c 0.12 , $\left.\mathrm{CH}_{3} \mathrm{OH}\right)$; UV $\left(\mathrm{CH}_{3} \mathrm{OH}\right) \lambda_{\max }(\log \varepsilon) 320$ (4.09) nm; IR (KBr) $\nu_{\text {max }}$ 1734, $1615 \mathrm{~cm}^{-1} ;{ }^{1} \mathrm{H}$ and ${ }^{13} \mathrm{C}$ NMR data see Tables 1 and 3 ; HRESIMS $m / z$ 351.1201 $[\mathrm{M}+\mathrm{Na}]^{+}$(calcd for $\mathrm{C}_{19} \mathrm{H}_{20} \mathrm{O}_{5} \mathrm{Na}$, 351.1208).

\section{Antimicrobial assays}

The microbial strains of Staphylococcus aureus, Escherichia coli and Monilia albicans were purchased from the Basic Medical College of Huazhong University of Science and Technology. The paper disk diffusion method ${ }^{23}$ was used as an antimicrobial test for compounds 1-19. About $0.1 \mathrm{~mL}$ of each sample $(200 \mu \mathrm{g}$ $\mathrm{mL}^{-1}$ ) was added to a piece of paper (6 $\mathrm{mm}$ in diameter). Each disk was dried in air and pasted onto a culture dish at $37{ }^{\circ} \mathrm{C}$ for $24 \mathrm{~h}$. Antibacterial activity was measured by the inhibitory zone diameter (IZD). Penicillin G, streptomycin and fluconazole standard antimicrobial susceptibility disks (Hangzhou Microbial Reagent Co., Ltd) were used as positive controls for Staphylococcus aureus, Escherichia coli and Monilia albicans, respectively. Each test was performed in duplicate.

\section{Cell viability assay}

The three cancer cell lines including B16 (mouse melanoma cell lines), HepG2 (human hepatocellular carcinoma cell lines) and MCF7 (human breast adenocarcinoma cell lines) were purchased from the cell bank of the Basic Medical College of Huazhong University of Science and Technology. Each of these cell lines were maintained in DMEM containing $10 \%$ fetal bovine serum, 100 units per $\mathrm{mL}$ penicillin and $100 \mu \mathrm{g} \mathrm{mL} \mathrm{m}^{-1}$ streptomycin at $37{ }^{\circ} \mathrm{C}$ in $5 \% \mathrm{CO}_{2} .90 \mu \mathrm{L}$ of the cell suspension $\left(1 \times 10^{4}\right.$ cell per $\mathrm{mL}$ ) was seeded in each well of 96-well cell culture plates for $24 \mathrm{~h}$. $10 \mu \mathrm{L}$ of tested concentrations of compounds 1-19 were then added to each well. After another $24 \mathrm{~h}$ of incubation, each well was treated with $15 \mu \mathrm{L}$ of MTT solution $\left(5 \mathrm{mg} \mathrm{mL}^{-1}\right)$ for $4 \mathrm{~h}$ at $37^{\circ} \mathrm{C}$. For MTT assay, the supernatant was discarded and $100 \mu \mathrm{L}$ of DMSO was added to each well. The optical density at $570 \mathrm{~nm}$ was measured using a microplate reader. Doxorubicin was used as the positive control. All samples were cultured in triplicate. The data (cell viability, measured by MTT assay) were normalized and expressed as a percentage of the control group, which is set to $100 \%$.

\section{Acknowledgements}

We thank the staff at the analytical and testing center of Huazhong University of Science and Technology for collecting the spectroscopic data. We are also grateful to Mr Xianggao Meng from Huazhong Normal University for X-ray analysis. This work was supported by the Natural Science Foundation of China (No. 31270394 and 21572073) and the Fundamental Research Funds for the Central Universities (No. 2016YXMS150).

\section{Notes and references}

1 Z. Y. Wu and P. H. Raven, Flora of China, Science Press and Missouri Botanical Garden Press, Beijing and St. Louis, 2011, vol. 20-21, pp. 437-459.

2 Z. Y. Wu, Flora of China, Science Press, Beijing, 1999, vol. 77, p. 19.

3 T. Takemoto, G. Kusano, K. Aota, M. Kaneshima and N. A. Emary, Yakugaku Zasshi, 1974, 94, 1593-1596.

4 Y. Saito, M. Ichihara, Y. Okamoto, X. Gong, C. Kuroda and M. Tori, Tetrahedron Lett., 2011, 52, 6388-6391.

5 M. J. Mao, C. S. Yuan and Z. J. Jia, Chin. Chem. Lett., 2004, 15, 794-796.

6 M. J. Mao, Z. D. Yang and Z. J. Jia, Planta Med., 2003, 69, 745749.

7 M. J. Mao and Z. J. Jia, Planta Med., 2002, 68, 55-59.

8 S. Zhang, G. Zhao, R. Li and G. Lin, Phytochemistry, 1998, 48, 519-524.

9 K. Masanori, N. Hiroshi, N. Tadataka, U. Akira and S. Fukushima, Chem. Pharm. Bull., 1985, 33, 4792-4797.

10 X. Jia, A. Gao, J. Gong, N. Li, X. Y. Hou, S. F. Ni, T. Zhao, F. Lu and Q. L. Chen, J. Anhui Agric. Sci., 2011, 39, 3955-3956.

11 A. Jin, W. M. Wu, H. Y. Yu, M. Zhou, Y. Liu, T. Tian and H. L. Ruan, J. Nat. Prod., 2015, 78, 2057-2066. 
12 A. Arciniegas, K. González, A. Pérez-Castorena, A. NietoCamacho, J. Villaseñor and A. Romo De Vivar, J. Nat. Prod., 2014, 77, 1304-1310.

13 X. Gao, C. J. Lin, W. D. Xie, T. Shen and Z. J. Jia, Helv. Chim. Acta, 2006, 89, 1387-1394.

14 X. Gao, W. D. Xie and Z. J. Jia, J. Asian Nat. Prod. Res., 2008, 10, 185-192.

15 Y. X. Wu, Y. J. Chen, C. M. Liu and K. Gao, J. Asian Nat. Prod. Res., 2012, 14, 1130-1136.

16 B. N. Su, Q. X. Zhu and Z. J. Jia, Phytochemistry, 2000, 53, 1103-1108.
17 J. C. Liao, L. Yang and Z. J. Jia, Chem. Res. Chin. Univ., 1999, 15, 67-69.

18 B. Fu, L. Yang, X. P. Yang, X. P. Li and Z. J. Jia, Die Pharmazie, 2000, 55, 947-952.

19 R. Phatchana and C. Yenjai, Planta Med., 2014, 80, 719-722.

20 Q. Wang, T. Chen, K. F. Bastow, K. Lee and D. Chen, J. Nat. Prod., 2010, 73, 139-142.

21 Y. Zhu, L. Yang and Z. J. Jia, J. Nat. Prod., 1999, 62, 14791483.

22 Q. Wang, T. Chen, K. F. Bastow, S. L. Morris-Natschke, K. Lee and D. Chen, J. Nat. Prod., 2012, 76, 305-310.

23 J. M. Andrews, J. Antimicrob. Chemother., 2001, 48, 43-57. 